\title{
"The Impact of African-American Female Leaders on Creating a Positive School Culture that Results in the Improvement of Student Achievement"
}

\author{
Dr. Beverly Ffolkes-Bryant \\ Adjunct Professor \\ The City College of New York \\ New York \\ Dr. Joyce R. Coppin \\ Assistant Professor, Mercy College \\ New York
}

\begin{abstract}
Historically, women and minorities have been underrepresented in school leadership positions. Furthermore, African American women faced substantial scrutiny during their professional careers and were obliged to take different routes to acquire administrative positions. This research will explore the journeys of successful African American females who are serving or who have served previously as school and district administrators in $21^{s t}$ century global environments. This research will describe how female African American principals and superintendents define and understand the influence of race and gender on their educational leadership experiences. Three theoretical research frameworks form the basis for this understanding and will be discussed: Critical Race Theory; Racial Identity Development Theory and the Black Epistemology.
\end{abstract}

The theoretical perspectives emerging from studying this research have enabled these women to develop a positive sense of self. These perceptions have impacted their conceptualization of leadership, their ability to deal with barriers they encounter, and to conceive effective strategies to attain a principal ship and/or a superintendency. The paper will discuss the formal and informal educational preparation of these African American women. Through their personal stories, case studies, research, and data from the New York City public school system, the reasons these women were chosen, as leaders will be elucidated. They had a reputation for developing teachers' instructional ability and were considered to be fair and consistent. Data will demonstrate they improved student outcomes. These leaders fostered distributive leadership and were able to cultivate leaders in their schools and districts. They were able also to communicate effectively with parents, community members and staff and to form community and educational partnerships.

Over the past decade, research has been devoted to bridging the gap in academics and opportunity experienced by African-American students. Missing from the dialogue however are the voices of African-American female leaders. Their voices will not only play an instrumental part in mediating cultural misunderstandings that occur in the classroom, but will also facilitate a much needed conversation in understanding gender and race by displaying different views on educational leadership.

African-American female school leaders have a multiplicity of positive and challenging experiences. They are resilient and spiritually-grounded which has aided them in answering the call to leadership.

The study of the lived personal, professional and sociocultural experience of African-American female school leaders may be helpful to educational researchers and practitioners, colleges and universities, boards of education, school districts, schools and all African-American females who aspire to become school leaders. By exploring the lives of these school leaders, greater insights may be gained to open the door to this underrepresented population. This research is valuable for professional development planning and educational leadership programs with the objective of recruiting, selecting, placing and retaining more African-American school leaders.

In their book, "Cultural Proficiency, A Manual for School Leaders", (Lindsey, Robins and Terrell 2009) the authors define "Cultural Proficiency" as a model for shifting the culture in the school or district; it is a model for individual transformation and organizational change. Cultural proficiency is a mind-set, a worldview, a way a person or an organization make assumptions for effectively describing, responding to, and planning for issues that arise in diverse environments.(For some people, cultural proficiency is a paradigm shift from viewing cultural difference as problematic to viewing cultural difference as the basis for cross-cultural interactions and ultimately personal change and transformation.)

Culturally proficient leaders display personal values and behaviors that enable them and others to engage in effective interactions among students, educators and the community they serve. 
At the organizational level, culturally proficient leaders foster policies and practices that provide the opportunity for effective interactions among students, educators and community members. Culturally proficient leaders address issues that emerge when cultural differences are not valued and even dismissed inschools and other organizations.

It is important to review the guiding principles of cultural proficiency to fully understand how we can embrace the voices of our African-American women educators:

1. Culture is a predominant force; you cannot not have a culture.

2. The group identity of individuals is as important as their individual identities.

3. Diversity within cultures is vast and significant.

4. Each group has unique cultural needs.

5. The non-dominant group creates a set of issues that the school system must be equipped to respond.

6. Inherent in cross-cultural interactions are dynamics that must be acknowledged, adjusted to and accepted.

7. The school system must incorporate cultural knowledge into practice and policymaking. In accordance with the guiding principles that serve students from non-dominant cultures must/should adopt and adjust to these students' cultures.

School systems are not accepting or implementing these guiding principles. There are highly qualified educators who accept the challenges that these students present and who do believe in these principles; however, they are not given the opportunity to make policy changes that will support these students and improve their academic achievement. Our paper will discuss how these highly qualified educators have successfully faced and responded to the "distinct set of issues" imposed by the non-dominant cultures in schools

The African-American female leaders in this study shared that they work to engage the community and build relationships with stakeholders. They reported also being courageous and clear in defining where they would take a stand. This has required knowing who they are and being true to personal values and ethics. African-American female school leaders reported having strong religious faith and benefitting from the love, support and encouragement of parents, family and friends. They identified listening as critical to their success. Mentoring new and aspiring African-American women principals/superintendents is one way they intentionally give back to the profession. They expressed the need to be continuous learners and to work hard while striving to achieve life-work balance.

Seven themes have emerged from the research conducted of these individuals who were interviewed for our paper: (a) the impact of race and gender in school leadership (b) caring for family and self (c) resilience and spirituality (d) importance of education and upward mobility (e) mentoring and networking (f) effective communication and positive working relationships and $(\mathrm{g})$ child advocacy and community partnerships. It is evident that beliefs and values at the individual level have taken a central role over the policies and practices of their specific organization. The professional experiences of these women took a nontraditional route to their leadership role.

Their rise to leadership positions were the result of their success in improving student achievement, outstanding personal and professional leadership characteristics and a reputation for being there and consistency. School leaders of demographically diverse schools play an important role in changing the dynamics that often occur in these contexts. Consequently, principals must have the leadership skills to revolutionize teachers' belief systems. Their energies are consumed with teachers' instructional practices and focusing on improving student expectations. This work to revolutionize the belief systems will facilitate teacher instructional practices and ultimately improve student outcomes.

They attributed their job attainment to student success, their ability to develop teachers, their being the most qualified candidate with a reputation of being fair and consistent. Overall, an attribute common to all of their stories of ascension was that a barrier to opportunity mindset did not bind them.

The research and experiences of these candidates focus on addressing critical demographic, cultural, and political changes and events in western countries currently. This is an important concept for school leaders due to changes occurring globally in education and the difficulties many countries have in dealing with the diverse cultures of their schools. There are countries that have experienced children and refugees coming into their country who are not familiar with the culture and system of education. The waves of people of different cultures and backgrounds have often caused conflict and the inability for educational systems to adequately educate these children and enable them to achieve their full potential. A model that has worked, based upon the Critical Race Theory, Racial Identity Development Theory and Black Epistemology, has been effective in certain areas of the United States. This model considers the educational crisis caused by significant changes in the demographics in students attending schools where they are not the dominant culture. 


\section{Critical Race Theory}

Critical Race Theory (CRT) investigates a paradox: how does racism persist despite its nearly universal condemnation by state policy and by the norms of polite society? Critical Race Theory developed out of legal scholarship; it provides a critical analysis of race and racism from a legal point of view.

CRT recognizes that racism is engrained in the fabric and system of American society. The individual racist need not exist except that institutional racism is pervasive in the dominant culture. When an individual commits small acts of racism, social scientists call the act "micro aggression", by which they mean one of those many sudden, stunning or despairing transactions that mar the daily lives of African-Americans and other people of color. These assumptions, in turn, continue to inform our public civic institutions - government, schools, churches - and our private, personal and corporate lives. Unlike traditional civil rights, which embraces instrumentalism and step-bystep progress, critical race theory questions the very foundations of the liberal order, including equality theory, legal reasoning, enlightenment, rationalism and neutral principles of constitutional law.

CRT identifies that these power structures are based on white privilege and white supremacy, which perpetuate the marginalization of people of color. CRT rejects the traditions of liberalism and meritocracy, which are based on the idea that law is neutral and moreover "color blind". CRT challenges this legal "truth" by examining liberalism and meritocracy as a vehicle for self-interest, power and privilege. CRT recognizes that liberalism and meritocracy are often stories transmitted through the lens of those with wealth, power and privilege. These stories paint a false picture of meritocracy that everyone who works hard can attain wealth, power and privilege because these stories ignore the systematic inequalities that institutional racism provides. Critical race theorists take the position that racism is ordinary and normal in contemporary society, integral to social practices and institutions.

Critical Race Theory began in the mid 1970's as a number of lawyers, activists and legal scholars across the country realized that the advances of the civil rights era of the 1960's had stalled and, in many respects, were being rolled back. The works of Derrick Bell and Alan Freeman have been attributed to the start of CRT. Bell and Freeman, frustrated with the slow pace of racial reform in the United States, argued that the traditional approaches of combating racism were producing smaller gains than in previous years. Through small acts of day-to-day experiences of "micro-aggressions", most African-Americans and other people of color demonstrated why hopes for "social integration" with whites seemed largely to have faded.

Unlike some academic disciplines, critical race theory contains an activist dimension. It not only tries to understand our social situation, but to change it. It sets out not only to ascertain how society organizes itself along racial lines and hierarchies, but how to transform society for the better.

A critical component of Critical Race Theory is the commitment to social justice and the active role scholars take in working toward "eliminating racial oppression as a broad goal of ending all forms of oppression". Most of the writing within Critical Race Theory has consisted of a sustained attack on the U.S. Supreme Court's race jurisprudence, particularly its constitutional jurisprudence. Critical race theorists have attempted to show how these jurisprudential developments, separately and together, block the possibility of political, economic and social redistributions that would disrupt systematic racism. Much traditional U.S. civil rights jurisprudence, and critical race theory in its early stages focused on cast racism against African-Americans. An example of one of these developments that ultimately did not disrupt systematic racism, according to Derrick Bell, is Brown vs. Board of Education. This landmark constitutional case that struck down de jure segregation in elementary education has become a historical artifact without contemporary significance given the resegregation of American schools. Racism may change in form but not in its insidious effect.

Prior Brown vs. Board of Education, in the seventeen states that had segregated school systems, 35 to 50 percent of the teaching force was black, said Fenwick, who has researched the displacement of black educators for her upcoming book, Jim Crow's Pink Skip: Public Policy and the Near Decimation of Black Educational Leadership After Brown.

Now, no state has anywhere close to those percentages of black teachers or principals, she said. According to the most recent federal data, about 7 percent of public school teachers, and 11 percent of public school principals are black.

Despite these challenges, most of the black teachers and principals in segregated schools pre- Brownhad better credentials than white educators, Fenwick said. "That's what we lost," Fenwick said. "We lost these credentialed, qualified people who had experienced integration in educational environments, who had played by the rules and come back (to teach in the South)"

American educational studies at Emory University, who extensively researched the records of black educators during this time period for The Lost Education of Horace Tate. 
There was an entire network of black educators who organized efforts to desegregate schools and provide equal access to transportation and school resources, even though they knew their efforts could result in jobs loss and even threats of violence, said Walker, who is also president of the American Educational Research Association. And inside the classrooms of segregated schools, there was a focus on civics and the democratic ideals. Black children were taught to aspire to greater things than the status quo or segregation, Walker said."They taught these children not to believe the wider societal messages, but to really believe they could be full participants in American democracy," she said. "Rather than being victimized by what America is not giving them, they are literally teaching these children to live in a world that does not exist." That purposeful education - including strong interpersonal relationships between teachers and black students went away when black schools were closed, and "you got rid of the people who knew how to do it." Walker said.

Linda Tillman, a professor emerita of educational leadership in the School of Education at the University of North Carolina at Chapel Hill, said after the Brown decision, standardized tests were used to "deny black educators the opportunity to teach". States implemented certification measures that led to black teachers being fired or to school districts not renewing their contracts, she said.

Another theme within Critical Race Theory has been an effort to understand how racism interlocks with other forms of oppression, including gender, class and sexuality. From the beginning, many critical race theorists regarded themselves as feminists and several addressed the failure of mainstream feminism to respond to the interests and perspectives of women of color. Later writers in this tradition sometimes refer themselves as Critical Race Feminists. Patricia Collins, whose Black Feminist Epistemology is part of this paper, is one example. The Critical Race feminists have produced a body of work that criticizes legal institutions and legal doctrine from the perspective of women of color. Their feminist's insights into the relationship between power and the construction of social roles, as well as the unseen, largely invisible collection of patterns and habits that make up patriarchy and other types of domination, have been essential to our studies of African- American women in education.

As we have the opportunity to hear the voices of African-American women in education, we should keep in the forefront of our mind three fundamental beliefs set forth in CRT. What do Critical Race Theorists believe?

1. Racism is ordinary, not aberrational- "normal science"; the usual way society does business, the common, everyday experience of most people of color in this country.

2. The system of white-over-color ascendancy serves important purposes, both psychic and material.

3. The "Social Construction" thesis holds that race and races are products of social thought and relation

\section{Racial Identity Development Thought Theory}

Research on racial identity development emerged from the experiences of African Americans during the 1960's civil rights movement, and has expanded over time to include the experiences of other racial groups. The concept of racial identity is often misunderstood and can have several meanings, which are derived from biological dimensions and social dimensions. Race is socially understood to be derived from an individual's physical features, such as white or black skin tone. The social construction of racial identity can be referred as a sense of group or collective identity based on one's perception that he or she shares a common heritage with a particular racial group. Racial identity is a surface-level manifestation based on what people look like yet has deep implications in how people are treated.

Racial and ethnic identity are critical parts of the overall framework of individual and collective identity. For some especially visible and legally defined minority populations in the United States, racial and ethnic identity are manifested in very conscious ways. This manifestation is triggered most often by two conflicting social and cultural influences. First, deep conscious immersion into cultural traditions and values through religious, familial, neighborhood, and educational communities instill a positive sense of ethnic identity and confidence. Second, and in contrast, individuals often must filter ethnic identity through negative treatment and media messages received from others because of their race and ethnicity.

These messages make it clear that people with minority status have a different ethnic make-up and one that is less than desirable within mainstream society. Others, especially white Americans, manifest ethnic and racial identity in mostly unconscious ways through their behaviors, values, beliefs, and assumptions. For them, ethnicity is usually invisible and unconscious because societal norms have been constructed around their racial, ethnic, and cultural frameworks, values, and priorities and then referred to as "standard American culture" rather than as "ethnic identity." This unconscious ethnic identity manifests itself in daily behaviors, attitudes, and ways of doing things. Unlike many minority cultures, there is little conscious instilling of specific ethnic identity through white communities, nor is differential ethnic treatment often identified in the media of white cultures.

Research reveals racial identity development is related to psychological well-being. Commitment of a racial identity may help to abate depressive symptoms experienced soon after experiencing discrimination, which in turn alleviates overall stress. 
Numerous studies show many positive outcomes associated with strong and stable ethnic identities, including increased self-esteem, improved mental health, decreased self-destructive behaviors, and greater academic achievement. In contrast, empirical evidence suggests that ethnic identity exploration may be related to vulnerability to negative outcomes, such as depression. Findings suggest this is due to an individual's sensitivity to awareness of discrimination and conflicts of positive and negative images of ethnicity during exploration. Also, while commitment to an ethnic group(s) is related to additional resources, exploration is related to a lack of readyaccess resources.

\section{Black Epistemology}

Epistemology constitutes an overarching theory of knowledge. It investigates the standards used to assess knowledge or why we believe to be true. Far from being the apolitical study of truth, epistemology points to the ways in which power relations shape who is believed and why. Black Epistemology or the Black Feminist Thought consists of ideas produced by black women that clarify a standpoint of and for black women. Becauseblack women have access to both the Afrocentric and the feminist standpoints, an alternative epistemology used to rearticulate a blackwomen's standpoint should reflect elements of both traditions. The search for the distinguishing features of an alternative epistemology used by African-American women reveals that values and ideas Africanist scholars identify as characteristically black often-bare remarkable resemblance to similar ideas claimed by feminist scholars as characteristically "female". This similarity suggests that the material conditions of race, class and gender oppression can vary dramatically and yet generate some uniformity in the epistemologies of subordinate groups.

The experiences of African-American women scholars illustrate how individuals who wish to rearticulate a black women's standpoint through black feminist thought can be suppressed by a white-male controlled knowledge validation process. Exclusion from basic literacy, quality educational experiences and faculty and administrative positions has limited black women's access to influential academic positions. While black women can produce knowledge claims that contest those advanced by the white male community, this community does not grant thatblack women scholars have competing knowledge claims based in another knowledge validation process. As a consequence, any credentials controlled by white male academicians can be denied to black women producing black feminist thought on the grounds that it is not credible research.

White men themselves do not necessarily manage institutions, paradigms and other elements of the knowledge validation procedure controlled by elite white men constitute the Eurocentric masculinist knowledge validation process. Scholars, publishers and other experts represent specific interests and credentialing processes and their knowledge claims must satisfy the political and epistemological criteria of the contexts in which they reside.

African-American women academicians who persist in trying to rearticulate a black women's standpoint also face potential rejection of their knowledge claims on epistemological grounds. Just as the material realities of the powerful and the dominated produce separate standpoints, each group may have distinctive epistemologiesalsoor theories of knowledge.

In valuing the concrete, African-American women invoke not only an Afrocentric tradition but a women's tradition as well. Some feminist theorists suggest that women are socialized in complex relational nexuses where context rules versus abstract principles govern behavior. The socialization process is thought to stimulate characteristic ways of knowing, one located in the body and the space it occupies and the other passing beyond it. Through their child rearing and nurturing activities, women mediate these two modes and use the concrete experiences of their daily lives to assess more abstract knowledge claims.

In traditional African-American communities, black women find considerable institutional support for valuing concrete experience. Black women's centrality in families, churches and other community organizations allows them to share their concrete knowledge of what it takes to bea self-defined black woman younger, less experienced sisters. Though not expressed in explicitly political terms, this relationship of sisterhood among Black women can be seen as a model for a whole series of relationships African American women have with one another.

Black women who achieve academic credentials face pressure from multiple sides. They must navigate between two conflicting epistemologies - representing white male interest on the one hand and Black female interest on the other. These scholars must constantly translate and more back and forth between these two frameworks. Those who accept such institutional assumptions are rewarded, but often at a person cost and those that challenge such assumptions face the risk of being ostracized.

\section{African - American Women Educational Leaders}

Historically, women and minorities are underrepresented among school leaders. African American women face substantial scrutiny during their professional careers and take divergent routes to acquire administrative positions. Women comprise approximately $84 \%$ of the teaching workforce in public schools in the United States, yet female leaders only comprise approximately $29 \%$ of principal ships in public schools and within the $29 \%$, African American women only hold $10 \%$ of the principals in public schools and $2.2 \%$ were superintendents (National 
Center for Education Statistics, 2011). This data suggest that as African American women ascend the ranks, their population numbers decrease substantially.

Women are "overrepresented in teaching" but "underrepresented in administration". The irony is women are the majority of students enrolled in educational administration programs.According to Dana \& Bourisaw (2006), the stigma of gender and racial biases are quite common in today's society, including school districts where women and people of color are often ignored for leadership positions (Dana \& Bourisaw, 2006). African American men and women encounter race and gender issues as part of society's "fundamental organizing principle of social structure" (Collins, 1998)

According to Johnson-Bailey and Tisdell (1998), there is limited research associated with the career development of women and a full exclusion of women of color. Although their attainment numbers are low, several women and minorities have been able to defy the odds and acquire this top ranked position. Nevertheless, a comprehensive overview of how they got there is still a mystery. Most researchers who have included African-American women as part of their studies have focused mostly on barriers and attributes they encounter as they aspire toward or toil in top rank leadership positions, without specifically identifying a common pathway.

Some researchers have found that African American women engage in self-efficacy (SE), counsel seeking, and spirituality as coping mechanisms when facing challenging situations (Rubino, Perry, Milam, Spitzmueller, \& Zapf, 2012). Bandura (1997) defined SE as individuals' belief in their ability to succeed in specific situations. He also characterized SE as a critical part of interactive human functioning.

Religiousness and spirituality have been linked consistently with positive indicators of well-being and the ability to find emotional support (Rubino et al., 2012). Allison and Broadus (2009) found that spirituality is a strength that African American women in leadership roles draw upon. Spirituality helps individuals to discover inner strength and resilience in determination as they travel the path of success. In their research, Allison and Broadus found also commitment to faith and authoritative leadership.

Rubino et al. (2012) found that African American women prefer individual support, including precise and contextual assistance, for personal development and often choose mentors to fill that role. Hobfoll and Shirom (2001) suggested that organizational characteristics such as providing resources could influence the leadership process and impact leadership development.

Rubino et al. (2012) found also that African American women endeavor to obtain, maintain, and engage in organizational activities that involve the voluntary and reciprocal exchange of resources for mutual benefit. Further, Rubino et al.characterized the conservation of resources (COR) as the motivation to strive to obtain and maintain resources. These resources include objects; circumstances; personal characteristics, including personality; and energies considered valuable (Jusoh, Ahmad, \& Omar, 2012). Individuals who have high levels of work-related resources are more likely to approach work with energy and enthusiasm (Hobfoll \& Shirom, 2001).

The leadership characteristics that African American women possess are very different from that of the traditional paradigm, and those leadership characteristics could prove to be beneficial to school boards and school district administrations. Recent research contends that African American women could bring cultural aspects to the position of leadership roles that traditionally have not been found in Caucasian male or female leaders (Eagly \& Chin, 2010). African American women leaders who possess the skill sets to serve in challenging school districts across the United States may aid in effectively reforming schools. In addition, they may also serve as role models for growing numbers of racial/ethnic students. Moreover, the presence of African American women serving in these leadership roles may yield positive benefits for the underrepresented youth in schools across the United States.

African- American women are subjected to power struggles with white men because of their gender, race, class and socio-economic culture. These intersectional oppressions make it inherent for Black women to create realities that challenge the interlocking nature of their role in society (Collins, 1986).

From this research, African American women gained a positive sense of self, developed their conceptualization of leadership, acquired skills to handle barriers, and conceived effective strategies to attain positions. Their personal stories, culture, case studies, student outcomes data, and performance assessments illustrate why these women were successful leaders. By sharing their personal, professional, and sociocultural experiences, African-American female school leaders may provide the insight needed for current and aspiring minority female school leaders. An increased effort to "recruit and retain women of color at all levels" of educational leadership is drastically important. Although women have made modest progress over the years, not much is known about the personal, professional, and sociocultural experiences of minority women as leaders in the educational field. 


\section{New York City Department of Education}

The New York City Department of Education (NYCDOE) is the largest school district in the United States, serving over 1.1 million students in over 1,800 schools. The department covers all five boroughs of New York City. A New York City School's Chancellor runs the New York City Department of Education. The current Chancellor is Richard Carranza.

The New York State legislature established the New York City Board of Education in 1842. Beginning in the late 1960 s, schools were grouped into districts. Elementary and middle schools were organized into 32 Community School districts and high schools were grouped into five geographically larger districts. There was one high school district for each borough, with the exception of Staten Island, which had high schools included in the southern parts of Brooklyn, in order to provide greater racial diversity. At this time, the mayor had control of the school system. In 1964, there were protests from the community to gain control of the schools to address inequities in school quality and leadership as well as racial disparities in student achievement. In 1969, In an effort to assuage the protesters, the mayor relinquished total control then city mayor John Lindsay organized the city school system into the Board of Education (made up of seven members appointed by the borough presidents and the mayor) and 32 community school boards (whose members were elected). The Community School Boards controlled elementary and middle schools, while high schools were controlled centrally by the Board of Education. Additionally, two high school districts were established - one for the education of special education students and another to provide alternative education for high school students who were not doing well academically, socially, and emotionally. In 2002, Chapter 91 of the laws of 2992 reorganized the city's school system again. Control of the system was returned to the mayor who began another reorganization and reform efforts. The Community School boards were abolished but the mayor retained the organization where the elementary and middle schools are in two 32 school districts the Board of Education was replaced by the panel for educational policy to work directly with the Chancellor, the head of the school system and is appointed by the mayor The name of the Board of Education was changed to the Department of Education, to demonstrate that the education system was under the mayor's authority and was to be controlled like any other department in the mayor's city organization.

New York is one of ten major cities in the United States in which the educational system is under the control of the mayor rather than an elected school board. (The other cities are Jackson, Mississippi; Boston, Massachusetts; Chicago, Illinois; Baltimore, Maryland; Cleveland, Ohio; Harrisburg, Pennsylvania; Philadelphia, Pennsylvania; Providence, Rhode Island; Los Angeles, California.)

The New York City public school system is the third most segregated large city school system after Chicago and Dallas. Black isolation in schools has persisted even as residential segregation has declined. As of September 2019, the Department of Education had 1,126,501 students excluding 119,551 students enrolled in Charter Schools. The student population was $40.6 \%$ Hispanic and Latino, 25.5\% African-American, 16.2\% Asian American, $15.1 \%$ Caucasian, , and 3\% Multi-Race. African-American and Hispanic children make up of $68 \%$ of the students citywide. Of the students, $20.2 \%$ were students with disabilities, $13.2 \%$ were English Language Learners and $72.8 \%$ are economically disadvantaged. Half of the city's schools have an enrollment of over $90 \%$ Black and Hispanic students.

For the 2018-2019 school year, student enrollment by borough was: Brooklyn - 339,985 students, Queens- 307, 114 students, Bronx - 236, 267 students, Manhattan - 177, 512 students and Staten Island - 65,623 students.

According to report by University of California, Los Angeles' (UCLA)Civil Rights Project, school segregation in New York is widespread and occurs not just in metropolitan New York City, but also in rural areas and in urban locales upstate. However, as the nation's largest public school system with 1.1 million students, the New York City Public Schools greatly influence the depth and breadth of the segregation problem. And a significant problem it is. Although the number of Asian and Latino students has dramatically increased since the late 1980s, exposure of these groups to white students has decreased. In fact, of New York City's 32 school districts, 19 had less than 10 percent white enrollment as recently as 2010. Some of New York City's schools, particularly charter and magnet schools, are identified by the authors of the report as being so segregated that they are classified as "apartheid schools."

At the time of this research report, the Department of Education's Central Leadership, under Chancellor Carmen Farina, One Senior Deputy Chancellor and four Deputy Chancellors (Teaching and Learning, Specialized Instruction \& Student Support, English Language Learners and Strategy and Policy). Out of the six senior leadership positions, only one (Senior Deputy Chancellor) was an African -American Woman, reflecting $20 \%$. There were 46 Community/High School Superintendents during that time. Out of the 46 Superintendents, only 10 were African-American Women, reflecting 21.7\%. At the time there were 6,200 administrators within the Department of Education (Superintendents, Principals, Assistant Principals, District Office Personnel) servicing the 1,800 schools. Because of the Department of Education guidelines at that time, we were not able to find out how many of these administrators were African-American women. 
In June 2018, then Chancellor Richard Carranza announced a new streamlined support system for the New York City's 1800 schools and his Leadership Team for the Department of Education. According to Chancellor Carranza, these changes "create a clear line of accountability from every classroom to the Chancellor, and better align resources and supports for schools to further the Mayor's and Chancellor's Equity and Excellence for All agenda." These changes will bring resources closer to schools and simplify supports for principals allowing them to focus on the day-to-day operations of their schools.

To better align supervision and supports for every school, Superintendents and Field Support Center Executive Directors now report to nine Executive Superintendents, who will be overseen by the First Deputy Chancellor. The new support and supervision system builds on the current structure in which superintendents supervise principals, and Field Support Centers provide targeted resources to schools.

The new system supports greater alignment between superintendents and Field Support Centers, with a localized Executive Superintendent directly and efficiently overseeing a small group of superintendents and one Field Support Center. This alignment will ensure that they are collaborating to best serve principals and students.

The Executive Superintendent positions offer increased capacity to help superintendents and Field Support Centers work together to serve schools efficiently and effectively. Each of these Executive Superintendents will oversee both community superintendents and high school superintendents in their districts, as well as the Field Support Center serving their districts. Executive Superintendents are in charge of their respective DOE Borough/Citywide Offices, overseeing the Community and High School Superintendents and Borough Office support staffs to ensure schools and families are served efficiently and effectively. They provide greater alignment between superintendents and borough offices to support school principals, educators, students and families.

Under Chancellor Carranza, Central Leadership with the nine Executive Superintendents changed from five to fourteen, reflecting a 36\% raise. The Senior Deputy Chancellor is now the First Deputy Chancellor. The four Deputy Chancellor's positions have been changed ( School Climate \& Wellness, School Planning \& Development, Early Education \& Student Enrollment, Community Empowerment Partnerships \& Communications). There are currently six African-American women under this leadership structure reflecting $42.8 \%$, a 22.8 percentage point rise from 2017. There are still 46 Community/High School Superintendents of which 10 are African-American women, still reflecting the $20 \%$ points from three years ago.

\section{The African-American Leaders Interviewed}

Through our research, particularly using the work of Patricia Collins, we asked the participants five questions (See Appendix). We convened all five women and the questions were given in a round table format. (Full transcript of the interview is attached in the Appendix).

At the time of the research, it was the Department of Education's policy that reviewers could not interview any person currently working at the Department of Education. This limited research done on persons who were retired. Five African-American leaders were interviewed, two Superintendents, two principals, and one DeputyNetwork Leader (Note: During Chancellor Klein, Networks were the primary building block for organizing school support because resources are easily accessible to schools. Network Teams visited often to provide support and build relationships with school staff. Networks were small cross-functional teams directly accountable to Principals and are rated annually based on student achievement results and Principal satisfaction. Networks enabled the creation of professional collaborative communities of educators.)

\section{MLB, Retired Community Superintendent, District 27}

MLB is a retired Community Superintendent in District 27 Queens where she devoted her educational career for 33 years.

In her role as Community Superintendent of twelve years, she worked closely with a Network Organization to analyze school progress reports, conduct School Quality Reviews, provide on-going quality professional development, and monitor and support instructional and organizational aspects of schools to improve teaching and learning.

Since beginning her career in District 27, one of the largest school districts in New York City, she served in a variety of educational roles. She began her teaching career instructing elementary school students with special needs in multi-cultural education. She taught all elementary school grades in both general and special education, including adults in a comprehensive high school equivalency program. Prior to her position as Community Superintendent, she served three years as Deputy Superintendent for curriculum and instruction.

Under the Department of Education's Citywide Restructuring Plan, MLB was endorsed by the Regional Superintendent to serve as a Local Instructional Superintendent in Region 5 (in District 27). 
She worked closely with network principals to develop their leadership skills that helped bring about steady academic improvement for students in English Language Arts and Math. MLB enhanced support of principals as they worked to create whole school change to better support students, including students with disabilities. This was evident in the number of Blue-Ribbon Schools, National Recognized Core Knowledge Schools, and schools with specialized programs that were established across the District.

In the early part of Michele's career, she served as an elementary school principal and assistant principal in both elementary and middle schools.

MLB holds a Bachelor of Arts in History, Master of Science, Teaching Students with Learning Disabilities, and an Advanced Certificate in Administration and Supervision from Brooklyn College.

MLB is the recipient of several awards and certificates in recognition of her dedicated work in education and community involvement.

\section{GTB, Retired High School Superintendent (Manhattan \& Bronx)}

GTB was a High School Superintendent serving and supporting over 80 schools in The Bronx and Manhattan. In this position she selected and appointed new principals, supervised and rated her 80 plus principals, and contributed to establishing supervisory procedures, practices and guidelines to more efficiently and effectively supervise high school principals.

She previously served as one of the Directors of School Quality in the NYCDOE's Division of Performance and Accountability. In this position, she worked to oversee the Quality Review process. She shared responsibilities in leading Quality Reviews, developing and facilitating training, reading reviews for quality assurance, monitoring the fieldwork of reviewers, and (worked collaboratively with colleagues in the development of a joint school review process and a "crosswalk" review rubric with the New York State Education Department.

GTBalso worked at the NYCDOE's Central Office, in the Office of Portfolio Development as the Director of School Reform and Support contributing to the support of phase-out schools, training leaders of new small schools, and monitoring and reviewing charter schools. She has also held the position of Local Instructional Superintendent in the former Region 7 in School Districts 20, 21 and 31. Geri is the former principal of August Martin High School in Queens.

GTB has a rich background as a pre-K through college educator. She received tenure as the Director of Guidance of Farmingdale Public Schools (K-12) and as a guidance counselor at both Thomas Jefferson High School and Queens Gateway to Health Sciences Secondary School. Other past employment includes Assistant Principal of Pupil Personnel Services at Jamaica High School, Counselor at the National Scholarship Service and Fund For Negro Students (NSSFNS)/Queens Talent Search Program, and Assistant Education Director at the South Jamaica Center for Children and Parents, Inc., preschool teacher, college adjunct professor and high school teacher.

GTB is completing her doctoral studies as a student at Nova Southeastern University. She is a graduate of Syracuse University; and, received her master's degrees from Long Island University and Bank Street College. She is credentialized as a Child Development Associate through Teacher's College, and completed the Paideia Institute certificate program at University of North Carolina, Chapel Hill.

\section{PG, Retired Principal, Public School 80 (Queens, N.Y.)}

PG started her educational career late in life. PG, a full-time parent, finished her Bachelors of Education degree at City College at night. PG has wasa School Aide, a Paraprofessional while at City College and upon graduation, was hired as a Kindergarten Teacher at the age of thirty-five.

PG taught kindergarten for ten years and during that time I received my Masters in TESOL, Then a Professional Diploma in Administration and Supervision. She became an Interim-Acting Assistant Principal in 1997, Assistant Principal and finally a Principal in 2002 of Public School 80.

Public School 80 housed the largest special education population in Southeast Queens in addition to the general education students that attended.

PG was awarded Columbia Cahn Fellow- awarded to distinguished principals in 2009. PG also received educational award from various Queens's politicians.

PG believes I that "No Man Is An Island". Using that philosophy PG ran a very successful school in a family atmosphere.

\section{SH, Retired Principal, Public School 98 (Queens, N.Y.)}

SH's teaching career began at Manhattanville Head start followed by a two-year stint at P.S.5K in District 16. After a two-year layoff, due to the city's fiscal crisis, SH was assigned to District 26 in Queens. 
For the next 12 years she taught at P.S.186 in grades K-2. During this period SH earned her Master's Degree and was nominated by her Superintendent to join The Assistant Principals' Preparation Program. . In 1989 to 1991, SH was appointed Interim Acting Assistant Principal at P.S.26Q in District 26. In 1992, SH made history by being appointed the first African-American principal in District 26 at Public School 98.SH was principal at Public School 98 for 23 years. Public School 98 had a reputation of being a very vibrant and successful school filled with the love and joy of teaching and learning

In 1989, SH earned special recognition as a Danforth Scholar

SH prides herself of these accomplishments and notes that early in her fifth grade teacher told her "she was not future teacher material" and credits her success through the love and support of her parents.

\section{AL, Retired Deputy Network Leader, NYCDOE}

AL entered the field of education as a science teacher and quickly rose to a position of principal; heralding ACORN Community High School, an institution greatly in need, particularly in regards to Math and English Language Arts. At the end of her first school year as principal, the school was removed from the School in Need of Improvement (SINI)list for ELA, at the end of the second year the school was removed from the SINI list, and became an A-rated school.

As a result of her accomplishments, AL was asked to become an Executive Principal of Murray Bergtraum High School. (NOTE: An Executive Principalis charged with the leadership of failing schools. The executive principal works with the school leadership to team to improve the school over three years.)

As a result of AL's leadership, she was chosen to become a Deputy Network Leader. AL and her team were charged with assisting forty schools in developing an academic environment that assures the needs of all students were met. AL was responsible for direct coaching of over fifteen principals.

In 2013, AL retired from the New York City school system only to continue her passion of supporting schools and schools leaders by agreeing to become one of the Regional Executive Directors for the state of New Jersey, 2014. In her new position as Executive Regional Director, AL and her team supported schools that were on the state list for failing schools. During her tenure seventy percent of the schools she supported came off of the state list. As Regional Executive Director, AL helped schools to develop protocols, policies and procedures, but most importantly how to meet the needs of all students.

AL has received many awards during her tenure as an educator most notably: Principal of the year award my local community and the Columbia Cahn Fellow- awarded to distinguished principal

\section{Summary of the African-American Educators Interviewed}

Historically, African - American Women and minorities are underrepresented among school leaders. This situation is a consequence of the divergent routes African- American women must take to acquire administrative positions and the substantial and unusual scrutiny they face during their professional careers.

African-American female school leaders have a multiplicity of positive and challenging experiences. They are resilient and spiritually grounded which aided them in answering the call to leadership.

However, as a result of the divergent routes and scrutiny taken by these women, it will be shown through the interviews in this study, that the African- American women gained a positive sense of self, developed their conceptualization of leadership, acquired skills to handle barriers and conceived effective strategies to attain positions. Their personal stories, culture, case studies, student outcomes data, and performance assessment illustrate why these women were successful leaders.

Over the past decade, research has been devoted to bridging the gap in academics and opportunity among AfricanAmerican students. Missing from the dialogue, however, are the voices of African-American female leaders. Their voices have the potential to play an instrumental part in mediating cultural misunderstandings that occur in the classroom, and to facilitate a much needed conversation in understanding gender and race by displaying different views on educational leadership.

Leaders of demographically diverse schools play an important role in changing the dynamics that often occur in these contexts. Consequently, principals must have the leadership skills to revolutionize teachers' belief systems. Their energies are focused on reshaping teachers' instructional practices and improving student expectations.

The student of the lived personal, professional and sociocultural experience of African-American female school leaders may be helpful to educational researchers and practitioners, colleges and universities, boards of education, school districts, schools and all African-American females who aspire to become school leaders. By exploring the lives of these school leaders, greater insights may be gained to open the door for this underrepresented population. 
This research can benefit development planning and educational leadership programs with the objective of recruiting and retaining more African-American school leaders.

These women shared that they work to engage the community and build relationships with stakeholders. They also reported being courageous and clear in defining where they would take a stand. This required knowing who they are and being true to personal values and ethics. African-American female school leaders reported having strong religious faith and benefitting from the love, support and encouragement of parents, family and friends. They identified listening as critical to their success. Mentoring new and aspiring African-American women principals/superintendents is on way they intentionally give back to the profession. They expressed the need to be continuous learners and to work hard while striving to achieve life-work balance.

Seven themes have emerged from the research of these individuals (a) race and gender in school leadership (b) caring for family and self (c) resilience and spirituality (d) education and upward mobility (e) mentoring and networking (f) effective communication and positive working relationships and (g) child advocacy and community partnerships. The professional experiences of these women took a different route to their leadership role. They created their job attainment to student success, their ability to develop teachers, being the only qualified candidate and a reputation of being fair and consistent. Overall an attribute common to all their stories of ascension was a "Barrier to Opportunity" mindset.

Five women who worked for the New York City Department of Education were interviewed for this paper. Two were District Superintendents, two were Principals of elementary schools and one was a Network Leader from the central office, overseeing thirty-two schools throughout the City.

Through our research, particularly using the work of Patricia Collins, we asked the participants five questions (See Appendix). We convened all five women and the questions were given in a round table format. (Full transcript of the interview is attached in the Appendix). Based on their interview, common trends have been noted.

There has been a legacy of struggle. For four of the five women, the first positions of leadership were in schools of predominantly African -American and minority students with high socio-economic needs. Three of the women expressed that there had been a North side / South side distinction of assignments noted; the "North" side refers to more affluent, white schools. Most women expressed that there was an understanding they would not be placed in those schools. The women expressed that they endured both subtle and not so subtle racism. One of the women was but old she could work there but not live there. Noted in the interview was lack of support; in other words, "you can have the position but you are on your own."

A consistent theme that emerged during the interviews was wanting to give students who "look like us" the opportunity to be the best they can be. The women shared a vocabulary grounded in nurturing: students who "look like us" were referred to as their children and the school was identified as their "family." As stated by one of the women, "...my whole basis of education in that community was to establish a family atmosphere." The theme of nurturing also applied to the adults in the school. As stated by one of the women interviewed, "Look at the adults that you lead....and be able to mentor, coach, teach, lead, and help them become better as grown people."

The theme of nurturing also emerged as the women discussed facilitative leadership. All of the women talked about the importance of nurturing in fostering distributive leadership; additionally, they noted that holding others accountable and distributing responsibility were also components of leadership. The women noted that there had to be room for them to each have a life outside their school; as stated by one of the women, African American women are often consumed by their job.

The women summarized the unique qualification of being an African American woman leader: "Knowing you are a role model - your children may never see someone who looks like them who is important, a leader - you care. You say you care and you show you care so the children know you care. And, yes, non-African - Americans may care, but they aren't as invested, (paraphrasing - they can't be as invested). You want these children to be your doctors, your lawyers, your educators." What emerged was that the women felt that their life experience as African-American women positively impacted their influence on their school communities.

Evident also in the discussion was that while these women successfully established themselves as leaders, when they left their jobs either to assume other positions or to retire, for the most part, they were not replaced by other African-American women. Some of the women interviewed noted they actively looked to recommend AfricanAmerican women and to hire people of color to assume educational leadership position 


\section{Interviewees}

\begin{tabular}{|c|c|c|c|}
\hline & Position & District & Ethnicity (Majority) \\
\hline Female A & Principal Elementary & 26 & \\
\hline Female B & Superintendent & 27 & African-American \\
\hline Female C & Superintendent & $\begin{array}{l}\text { High School, Manhattan } \\
\text { \& Bronx Zones }\end{array}$ & $\begin{array}{l}\text { African-American. } \\
\text { Latino }\end{array}$ \\
\hline Female D & Principal Elementary & 28 & African-American \\
\hline Female E & Deputy Network Leader & Citywide & $\begin{array}{l}\text { African-American. } \\
\text { Latino }\end{array}$ \\
\hline
\end{tabular}

\section{Limitations of the Study}

Data collection and analysis were confined to the participating five African American female school leaders who previously lead in various positions for the New York City Department of Education. This research study did not account for the experiences of other minority females who are currently employed with the NYCDOE. The only data collected were study participant interviews. Participants were not observed in their daily routines as principals, superintendents and central office administrators. Teacher perspectives of participants' leadership style and ability were unaccounted for in this study. Researcher bias was a crucial component of the methodology and could not be completely omitted. Although these strategies were advantageous in decreasing researcher bias, qualitative research takes into account the researcher's experiences. As a result, the conclusions drawn in this study were subject to other interpretations and analysis

\section{Bibliography}

Atkinson, D. R., Morten, G., \& Sue, D. W (1988). Counseling American Minorities: A Cross Cultural Perspective (3rd Ed.). Dubuque, IA: Wm. C. Brown Publishers

Birhane, Abeda (2016). Black Feminist Epistemology (blogpost). Dublin, Ireland; Wordpress.com

Bandura, A. (1997). Self-efficacy: The Exercise of Control. New York, NY: Freeman.

Chavez, Alicia Fedelina \& Guido-DiBrito, Florence (1999). Racial and Ethnic Identity and Development. New Directions For Adult \& Continuing Educationno. 84

Chen, Grace (2019). "New York's Schools are the Most Segregated in the Nation”. New York, NY; Public School Review

Collins, Patricia Hill (1990). Black Feminist Thought in the Matrix of Domination. In Patricia Hill Collins, Black Feminist Thought, Knowledge, Consciousness and the Politics of Empowerment (pp.221-238). Boston. Unwin Hyman

Dana, J. A., \& Bourisaw, D. M. (2006). Overlooked leaders. American School Board Journal, 193(6), 27-30. Retrieved from http://web.ebscohost.com.fetch.mhsl.uab.edu

Delgado, Richard, Stefancic (2001). Critical Race Theory; An Introduction. New York; New York University Press

Eagly, A. H., \& Chin, J. L. (2010). Diversity and Leadership in a Changing World. American Psychologist, 65(3), 216-224. http://dx.doi.org/10.1037/a0018957

Favro, Tony (2011). "US Mayors Are Divided About Merits of Controlling Schools." Citymayors.com. (Retrieved September 12, 2011) McLean, Virginia, USA Today

Harris, Angela P (2012). Critical Race Theory (from The Selected Works of Angela P. Harris. University of California

Helms, J. E. (1995). An Update of Helm's White and People of Color Racial Identity Models. In J. G. Ponterotto, J. M. Casas, L. A. Suzuki, \& C. M. Alexander (Eds.). Handbook of Multicultural Counseling (pp.181-191). Thousand Oaks, CA: Sage.

Hobfoll, S. E., \& Shirom, A. (2001). Conservation of Resources Theory. In R. Golembiewski (Ed.), Handbook of organizational behavior (pp. 57-80). New York, NY: Dekker.

Johnson, Kimberly Gales (2013). African American Women Superintendents: Pathways to Success. LSU Doctoral Dissertations. 2069. https://digitalcommons.lsu.edu/gradschool_dissertations/2069 
Johnson-Bailey, J., \& Tisdell, E. J. (1998). Diversity Issues in Women's Career Development. New Directions For Adult and Continuing Education, 1998(80), 83-93.

Jusoh, M. M., Ahmad, A., \& Omar, Z. (2012). Mediating Role of Work-Family Psychological Contract in the Relationships Between Personality Factors and Job Satisfaction. Journal of Human Resource and Adult Learning, 8(2), 60-64.

Lindsey, Randall B., Terrell, Raymond D. (2009). Cultural Proficiency; A Manual for School Leaders Thousand Oaks; Corwin, A SAGE Company

New York State Education Department. (2019). "Demographic Snapshot - Citywide, Borough, District and School". (Retrieved October 2019). New York Times, November 5, 2012

Revere, A.B. (1987). Black Women Superintendents in the United States: 1984-85. The Journal of Negro Education, 56(4), 510-520.

Robinson, Armentress D (2014). Personal, Professional and Sociocultural Experiences of African-American Female School Leaders. Alabama; Alabama Journal of Educational Leadership (Volume 1, September 2014)

Rubino, C., Perry, S., Milam, A. C., Spitzmueller, C., \& Zapf, D. (2012). Demand-Control Person: Integrating the Demand-Control and Conservation of Resources Models to Test an Expanded Stressor-Strain Model. Journal of Occupational Health Psychology, 17(4), 456-472. doi:10.1037/a0029718

Shakeshaft, C. (1999). The Struggle to Create a More Gender-Inclusive Profession. J. Murphy \& K. S. Louis (Eds.), Handbook of Research on Educational Administration (pp. 99-118). San Francisco, CA, JosseyBass

Shakeshaft, C., Brown, G., Irby, B. J., Grogan, M., \& Ballenger, J. (2007). Increasing Gender Equity in Educational Leadership. Handbook of Gender Equity in Schools. Mahwah, NJ: Laurence Erlbaum Associates.

Smith, Angela Moseley (2008). African American Women Superintendents: Pathways to Success. Louisiana. Doctoral Dissertation. Southeastern Louisiana University.

West, Augustina Biney Amissah, (2018). African American Women in New York State Who Overcame Barriers to Become Superintendents of Schools. Education Doctoral. Paper 394.

Will, Madeline (2019). 65 Years After "Brown v.Board", Where Are All the Black Educators? https://www.edweek.org/ew/articles/2019/05/14/65-years-after-brown-v-board org/ewarticles/20119/0514/

\section{Appendix}

Appendix 3

New York City Department of Education Student Enrollment by Borough

\section{A Portrait of Segregation in New York City's Schools}

The landmark decision that outlawed segregation, Brown v. Board of Education, was handed down 58 years ago this week. In its wake, school systems undertook desegregation efforts that peaked in the 1980 s. Since then, schools across the country have been going through a process of de facto resegregation. In New York, efforts over the years to reduce the segregation of schools have had little effect. Related Article *

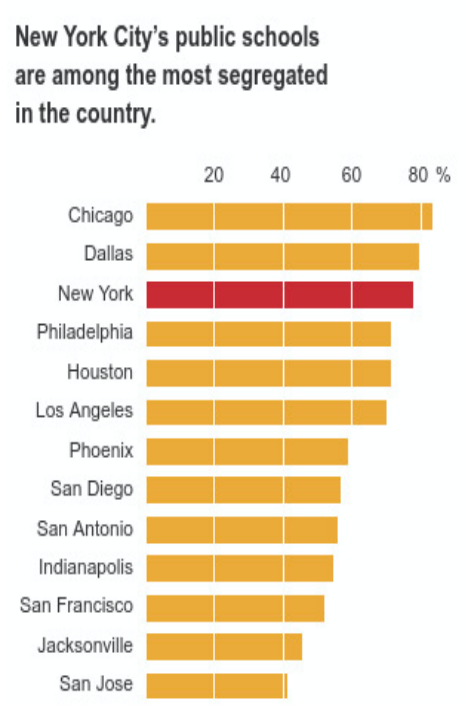

Percentage of students that would have to move to achieve integration among blacks and whites in the largest U.S. cities, 2009-10
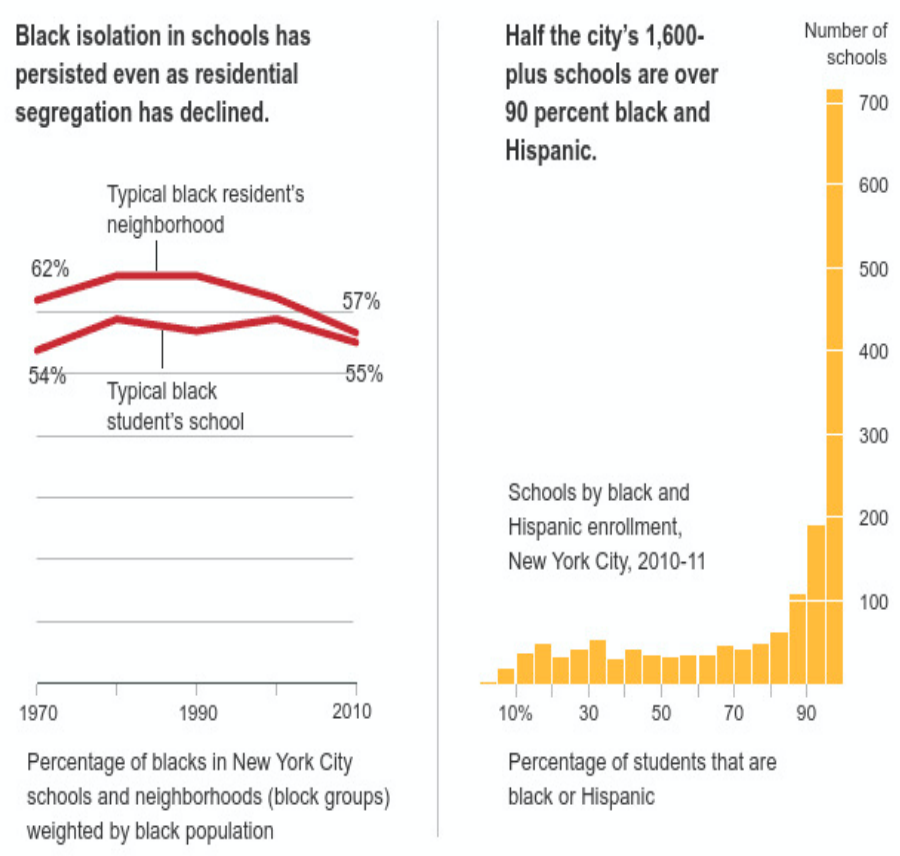


\section{Appendix 3}

African- American Women Educators "Symposium"
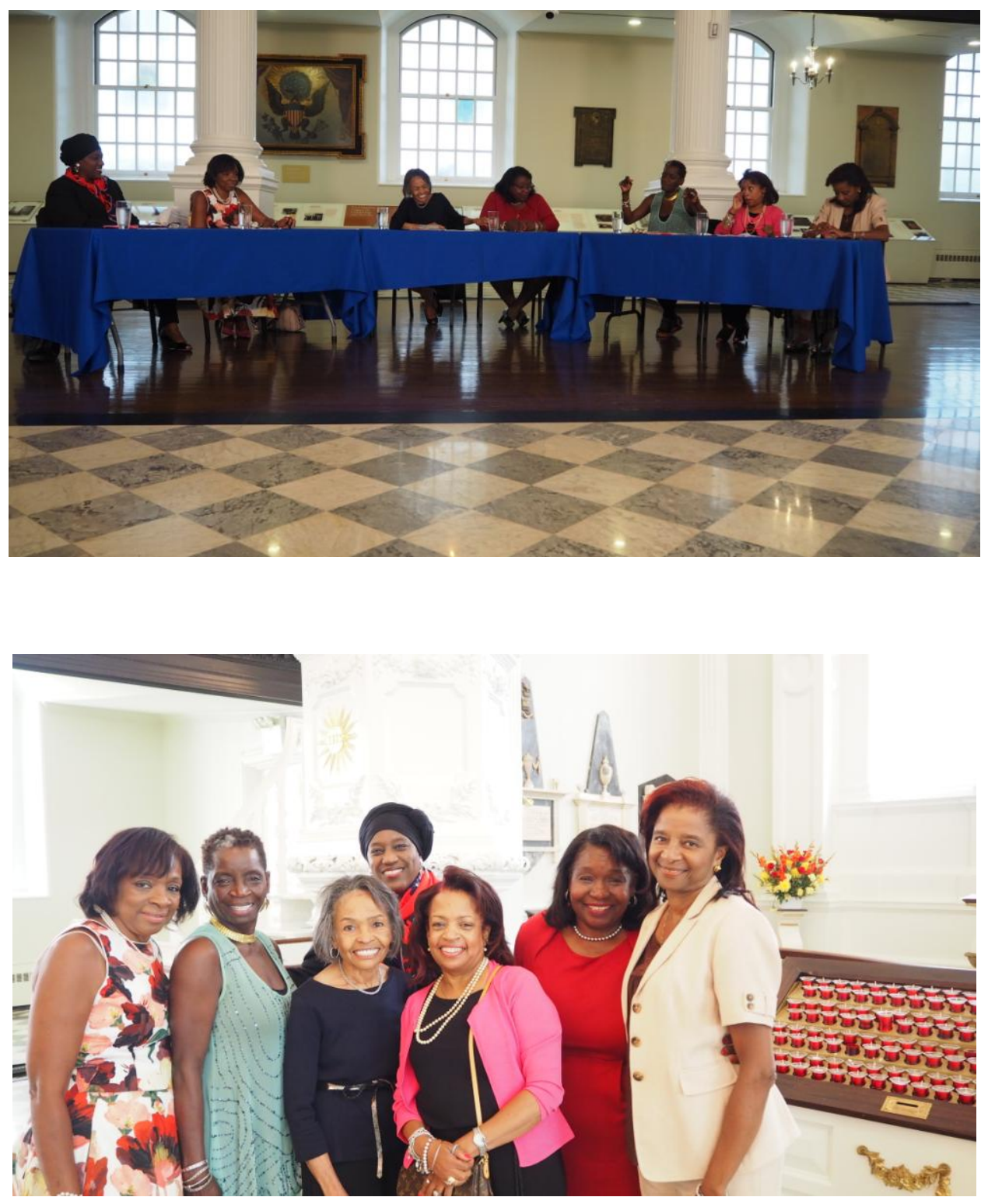

\section{Appendix 4}

Interview Questions for the Panel

1. Background

Please tell us a brief introduction of yourself.

2. What were some of the barriers that you faced in attaining a school and/or district leadership position in education? How did you overcome these barriers? Be specific

- Interlocking social systems (civil rights, history, race, class, gender)

- Politics

- Succession planning

- Sustainability

- Academic community

- Social thoughts

3. As an African-American female, what makes you uniquely qualified to be a school/district leader? Consider such qualifications as:

- Lived experiences (Collins, p. 276)

- Use of dialogue (Collins, p. 279)

- Personal accountability (Collins, p. 284)

- Ethics of caring (Collins, p. 282) 
4. What strategies - personal, political, professional - did you utilize that helped you to become an educational leader? You may wish to consider the following:

- Personal - gender, mentor, networking, race, politics

- Professional - pursuing an advanced degree, involvement in community, development of human relations skills

5. How is your school or district better you led it? What changes did you make? Please provide evidence e.g. student achievement data, college enrollment, collaborations with parents and educational institutions

\section{Appendix 5}

Educator's Panel

Sheila Huggins, Paulette Glenn, Geraldine Taylor-Brown, Andrea Lewis, Michelle Lloyd-Bey

August 8, 2017

TRINITY TELEVISION

(Background Conversation)

BB: Historically, women in minorities are underrepresented among school leaders. African American women face substantial scrutiny during their professional careers and take divergent routes to acquire administrative positions. The workshop will describe how African American female educational leaders understand and characterize the influence of race and gender on their leadership experiences. Three theoretical frameworks form the basis for this understanding. Critical Race Theory, Racial Identity Development Theory, and the Black Feminist Thought Theory.

From this research, African American women gained a positive sense of self, developed their conceptualization of leadership, acquired skills to handle barriers, and conceived effective strategies to attain positions. Their personal stories, culture, case studies, student outcomes data, and performance assessments illustrate why these women were successful leaders. JM: This video will be shown at an international conference of educators from around the world. The topic for or the title for the workshop is The Impact of African American Female Leaders on Creating a Positive School Culture that Results in the Improvement of Student Achievement. Participants in the workshop will develop a possible plan to apply the practical experiences and conclusions reached from these leaders to determine the use and placement of such personnel as yourself in various global educational settings.

BB: We've gathered today in this video five African American educational leaders who have achieved through their schools, districts, and ... oh, all right. I'm going to do it again.

(Background Conversation)

BB: Today, we have gathered around the table five African American women leaders who have succeeded in their roles either through their schools, through their districts, or through Central Department of Education. We have with us Miss Sheila Huggins, Former Principal of Public School 98 in District 26, Miss Paulette Glenn, Former Principal of PS 80 in District 28, Miss Geraldine Taylor-Brown, Former Superintendent of Manhattan and Bronx High Schools for the New York City Department of Education, Dr. Andrea Lewis, Network Leader for the Department, Former Network Leader for the Department of Educational, and Miss Michelle Lloyd-Bey, Former Superintendent for District 27 Queens, for the New York City Department of Education.

JC: It should be said that Dr. Beverly Folks(?) and I, Joyce Coppin, have also been superintendents in the New York City School System and so all of us form a group of female leaders who have been able to achieve which is generally understood to be outstanding achievements for students in our schools. Okay?

BF: Okay. So good afternoon, ladies. Can you please tell us a brief introduction of yourself? And we'll start with Miss Huggins.

SH: Of course you would. (Laughter) First and foremost, I'm born and bred in New York City and I'm a product of what was once known as the New York City Board of Education. I was granted the opportunity to be a part of a program sponsored by the late and great Dr. Nellie Dunkin, and I was a teacher and an administrator for 41 years in total, 23 of those years as Principal of PS 98.

JC: Thank you. Miss Glenn?

PG: Hi, I'm Paulette Glenn, Former Principal of PS 80 in Queens. I always wanted to be a teacher, I never intended to be a principal. I started out as a school aid, then I went to a para, then a school teacher, then an assistant principal, and then a principal for the past, total of 25 years I spent in the Department of Education. So, I've come full circle in this profession.

GTB: Hi, my name is Gerry Taylor-Brown, and I think like Paulette, I've kind of come full circle. 
I am a pre-K through 16 educator. I've been a teacher and Assistant Ed Director at a Head Start Program pre-K. I've been a 7-12 guidance counselor, and assistant principal, and English teacher, a principal (Laughs), a local instructional superintendent, a superintendent, district person down at the Central Department of Ed, but also on Long Island I was a director of guidance kindergarten through 12, and I've been adjunct for both Fordham and a graduate program in College of New Rochelle, and in undergrad.

So yes, I've kind of run the gamut. And I've worked for every borough in the City of New York for the Department of Education, including Staten Island. (Laughter)

AL: Good morning. Like Sheila, I am a product of the New York City Board of Education at that time. I entered education as a second career. I, unfortunately, became very ill and gave up the career I chose to do and my sister said, who was never a teacher, "Go into education. It's easy to teach. You have the summers off." But that being said, I entered as a teacher, worked my way up as an assistant principal, principal of a school that was a failing school, and worked very closely because it was my passion to make sure students achieved.

Turned that school around, became an executive principal, and then a network leader, and retired. And now I actually do work in New Jersey doing the thing that I love, making sure that minority students get the education they deserve.

MLB: Thank you. Good morning. I grew up in Brooklyn, New York and I'm the product of the New York City Public Education System. I am Michelle Lloyd-Bey. I come from a long line of educators, both here in America and in the West Indies. And I knew from an early age, about seven years old, that I wanted to be a teacher. I never would have believed that I would have retired having served the Department of Education in New York City for 33 years in so many different capacities in education.

I've been a special education teacher, a general education teacher, and a multi-cultural cluster teacher. I've been a dean. I've been an assistant principal in an elementary and a middle school. I've been a principal of two schools. I've been the Deputy Superintendent of District 27 and I've been the Superintendent for 12 years. And I feel very proud of just having been an educator at all, but especially an educator in District 27.

JC: So the first question, and we'll go around the table, what were some of the barriers you faced in attaining a school and/or district leadership position in education? And how did you overcome these barriers? Miss Huggins?

SH: Okay, I didn't really experience a barrier per se. When I entered District 26 as a teacher and I was assigned to a school I was the second African American teacher in that school. And that was in 1977. The first teacher, African American teacher, was assigned in 1954 so there was that big gap. Anyway, I had a wonderful experience being in District 26, exposed to some of the brilliant minds, and I got a lot of support and encouragement. And I really enjoyed what I did and it was evident in my classrooms when anybody would enter.

And one of the people that would come and visit was the then Superintendent, Irwin Altman. And he was always thrilled to see the kinds of activities that my students were involved. Now at that particular time there was concern that there were no African American principals in District 26. And he was the one that encouraged me to pursue this position. And so, after several interviews I was granted the appointment to PS 98 in Douglaston.

It was an interesting experience. Because where my school was located is in the well-heeled community of Douglaston and its white Anglo-Saxon. And there was a kind of expectation that only certain people could live in the community. For example, if you were Asian you had to live on the southern side of Northern Boulevard and I knew of and learned of people who were Jewish who denied who they were so that they could be embraced by the community and be a part of the Douglaston club.

When I was appointed there was a parent who came to me and she said, "Oh, well, welcome to our school. We're glad to have you, but you know you can't live here." And so with that, I thanked her and I said, "Well, I really don't want to live here. You have mosquitos, raccoons, and cesspools," and that offended her. (Laughter) But that was the kind of attitude and spirit that I was contending with quite frequently, but I did not necessarily go in any kind of political avenue to get my position or to maintain my position.

I knew who I was and what I believed in and I stood my ground in terms of what I thought was best for the school. And I did get pushback at times, but again, I stood my ground and I lasted for 23 years.

JC: Thank you. Miss Glenn?

PG: Well, I would say that the politics that I saw, not necessarily overtly experienced, was the division in my district. So, my school was on the South Side and was, is predominantly black and that's where all the black principals were. There were a few white principals, but for the most part black principals. On the North Side, Forest Hills side, Rego Park, mainly white. So, the dividing line was the problem that I experienced. 
Not so much that I wanted to cross that line, it was just so, so stark. You just, when you went to a meeting and we all sat together you could clearly see that was the North Side, this is the South Side.

Now my school was a well-kept secret because it was small and quaint, and it was like in a little corner. I was actually the last school of District 28 . So it was really quiet. It's tree lined streets and, you know, mom and dad, and full families. The cooperative is adjacent to the school along with two other schools on the triad.

So it was my elementary school, Middle School 72, and another elementary school on the other side. But in the co-op, 90 percent of it back in the day was Jewish and across the street was their temple.

So historically, I saw the change in the community and the environment, but I never saw a big change in leadership across the district as a whole until, I want to say, '99, 2000, you saw a little crossover, but for most of the time you knew where you were going to end up if you were appointment. You knew. And I didn't really buck it because the goal was to be the best that I could be where I was and to be that role model for my babies in the community. But I would say up until Dr. Bryant came we saw a big division line in District 28.

GTB: Wow. I know the North Side and the South Side story and as you were speaking I thought about my experience as a principal in the borough of Queens because on the North Side there were no, there were very few, I don't even know if there were when I first started principals of color, but on the South Side.

W: Yes.

GTB: There were plenty of us. And the data had been plummeting academically for students. One of my students and her mom, the PTA president, said, "When this school started, when my school started it started in greatness. It was named after a very great man and he had done outstanding things. And they only admitted children based on attendance. If you had 90 or more percent attendance you would be admitted." So of course, those were kids that were going to school, good data, parents involved.

By the time I got there had been two white male principals, a white female principal, a black male principal, and here I come. And my PTA president and her daughter said, "They let a woman go into outer space, Mae Jamison went into space in '92, before they would let a black woman come and be a principal or leader of this school. There was a show on years ago called Beulah, it was about a maid, and we started calling it "the Beulah Syndrome."

We had to come in and clean up the mess from everybody else to make an impact on data for students, the culture and the climate, but the school had to be at the edge of almost falling off the mountain they came.

W: Yes, yes, it's true.

GTB: But you know what? It was okay. Because I had an opportunity to interview for a North Side and a South Side school and when the results came back they were saying, "Well, you know, they want to take you to Level Two for the South Side school." I said, "No, I want that other school." (Laughter) Ernie Logan, who was in the union at the time, called me up and said, "Gerry, it's the same superintendent for the schools. He's saying you're taking this school. He's not going to give you the other school. (Laughs)." It was okay. It worked out well. I loved where I was placed.

My son said to me that he thought I would make a better impact for the community at a South Side school. So, I'm glad to be part of the South Side and I'm glad that we were able to make an impact, but I think the barriers were dealing with not just race, but also with gender.

W: Right.

GTB: And especially at the high school level because almost all the principals were male.

W: That's right.

GTB: So that's my little story.

W: That's true.

AL: I was a principal of a high school. My entire career as a teacher, I was a middle school teacher. And I was middle school teacher in Ocean Hill(?), Brownsville, so I didn't really feel the impact of racism or being able to move up. Ernie Logan did come into my classroom. So, at that point I was doing the workshop model before it was even called the workshop model. And he strongly suggested I become a teacher mentor and mentor some other teachers. So I was happy to do that, excuse me, to do that to make sure that children that looked like me received the education that they deserved. So that was important to me.

I didn't encounter any barriers. Any job that I applied for I actually got the job.

But the barriers came when I actually worked with the Acorn Organization to start a school in Crown Heights that was supposed to be a community school. A school that the community could be proud of, that really educated kids and made sure that kids that looked like me could go to Harvard. And I was, actually able to 
accomplish that.

So, the year that I left we had a couple of kids that did get into Harvard in some of the top tier schools and that was what was important to me. That although I wasn't on the North Side, per se, that the school that I created and worked, the team I worked with, we created a school that could be on the North Side. So, when the community changed a lot of the parents did want to bring their children into the school, we had no seats. Literally, we had no seats.

But it was really built for kids to be proud of who they are. To make sure that they could say, you know, we talked about the sagging pants this morning, right? That wasn't allowed, but I taught the kids, we taught the kids collectively to be proud of who you are. And that was more important to me. And as a result, I was asked to take over a school on the North Side, which became a challenge that I couldn't have envisioned in that the school had previously never had a principal of color and all of the staff was white.

I might have had a sprinkling, maybe 15 out of 330 staff members, I might have had 15 people of color or minority people. And I decided I was going to interview these teachers. You know, talk to them. Tell them a little bit about who I am and why I'm here. And I encountered comments like, "We need some more white Asian kids. They're more motivated. We don't need an executive principal." Or the union leader who sent me an email because I decided to take some of the staff members to Hilton Head for a conference and sent me an email where I could get fried chicken and watermelon.

And so, through all of that I was determined that I was still going to make a difference because the students looked like me. Right? So, the students were students who needed to have good education. So I worked really hard against, I'm not going to say all the political structures, but no one really cared about the school. The school, to your point, had failed for nine years. It went from being a second-tier school with the complexion of the students in the school were not that of minority students to, when Kline(?) came in and said, "We're having open enrollment," and kids of color could apply to that school, the school began to fall.

Teachers weren't held accountable, no one was held accountable. Nine years later they decided, "Okay, well, I guess we'll have a minority woman come in," because I think it was the perspective that we bring to the table about working with kids of color and being able to make sure we're teaching those kids to have a better outlook on life and a better education. It's why sometimes we're granted that opportunity to go to those other schools. And I did what I did to clean up the school, so to speak, and make sure that the students there got the education that they deserved.

MLB: Yes, that's interesting. We were talking about barriers. You know, you don't know there's a barrier sometimes until you're in the barrier, until it hits you in the face you don't even know what's going on. Myself, like a lot of my peers and my colleagues, other African American school leaders, we were so motivated and passionate and the only thing we wanted to do was a good job.

And so, when I received the first opportunity to go into an elementary school as an interim acting principal I was so excited. I said, "Oh, I'm going into this wonderful school." And it was my son who shared with me. He says, "You know, Mom, be careful because there's a lot of shootings in the neighborhood there." And so, I didn't even let that deter me. I maintained my passion to get into the school and the only thing I wanted to do was a good job. Well, I did a good job. I had an assistant principal, two assistant principals and one of them was absolutely stellar. And we got in there and for almost two solid years we worked on the curriculum, we worked on the staffing, we tried to build a positive culture of change.

We did professional development. And I was so excited, but in my school district at that time if you were an interim acting school leader you could not be appointed. I still remember the day when the superintendent called me into her office to tell me that I wasn't going to get the school. Now you have to know, oftentimes African American females, we go above, beyond, and beyond the call of duty.

I was in the building on the weekends. I was there walking the buildings on Sundays. I was calling people on the weekends. I had put my heart and soul into that position. So, of course, I broke down. But the interesting thing, the superintendent turned to me and said, "You know, you really shocked me. I didn't think you could do the job." And I didn't believe she was saying this to me.

So, it told me that a lot of times we go into certain schools in communities and they may be affluent community school districts, but they have pockets of poverty. Those schools are overlooked. They're a little neglected. No one pays them any attention.

So even though my parents, my school community went to the media, they went to the newspapers, they got everyone around go to the district office and protested I still wasn't able to get the position. So what did it tell me again? That I had better be ready. I better be more ready than anyone else.

So, what I had to do was I had to start getting myself aligned with community people, community leaders, 46 
started becoming more visible. I thought I was visible, becoming more visible, getting involved with the NAACP, the National Association for the Advancement of Colored People in my neighborhood.

I also took up the invitation of a coach, Abby Kestle(?), at the time. She invited me to her home and she says, "I will work with you. I will mentor you and coach you." And so that I said, "By the time I go to the next C-30 process I am going to knock it out of the water, the interview.

Well, I did. And the two schools that I interviewed for, the community wanted me so much that when the superintendent called me in again she asked me, "Which school do you want?" I couldn't imagine her asking me that, but of course, I took the school where I felt, and I think, Gerry, you said something about that, where I felt I could do the most good. And I took a school in the Far Rockaway area and I became eventually the appointed principal to that school. But this was a very interesting experience for me.

JM: Okay, I'm going to break it up so that you can respond together. It's not this way or that way. But did any of you have any barriers as far as politics in your position? And this is a free discussion.

PG: I would say parental politics. When I first walked into my building it was school board members of color that would come to me and say things like, a man in particular, "Oh, well, what are you going to do?" You know, "What's in it for me or my kids?" You know, sometimes you think the politics are far reaching and it's sitting right next to you. And I think that was the biggest mindblower to me, to have people that were of my community where ...I actually lived where I worked. You know, it wasn't like I had to travel. I could almost walk to work. And to hear this coming out of several of their mouths like, "Well, what's in it for us?" or "Why should we vote for you to be the principal? Why should we do this?"

I think that was big for me because it was a letdown. I would think that I would get the support. And although I did get it eventually, I just felt that this was something I shouldn't have had to prove of myself. You understand? That was something. You're of me so you should be like this with me. Why am I standing up here trying to convince you of who I am? So that annoyed me.

JM: Did anybody else experience what Paulette had?

AL: I think I do. Actually, I think I do. You know, getting back to that comment about fried chicken and watermelon, I sent that up the ladder. Right? Because I was appalled that someone would send me that email and think they were going to get away with it. And it was a, you know, a white gentleman and I use the word "gentleman" loosely. And he was determined, you know, as I said, I was the first minority or African American principal and I came in as an executive principal. And in his words, he saw it as a personal affront to the teachers that they were stellar teachers and they didn't need me.

And when I did, the superintendent at the time said to me, "Oh, Andrea, he's just trying to tell you where to find a good meal." Well, you know. So, I thought instead of supporting me, you know, you are going to then have this conversation with me. So, we had a different conversation. Because at that point I'd put in over 25 years in the Board of Ed and once you hit that 25 mark, you know, it's real

\section{W: That's right.}

AL: It becomes very honest about I've worked, as you said, I've worked, I've done that. Where at eleven o'clock at night I'm in that building, especially before C-30. Not at C-30, the quality review. You know, I'm in that building making sure. Although I held everyone's feet to the fire every day, but you want to make sure the final touches are there because you know you're going to be looked at differently than everybody else. Right? Than everyone else. So, we had to have a different conversation about support and the fact that I do know how to spell lawyer. (Laughter)

So we had that conversation. And everyone that wanted to send it the next day, it's like, "Oh, Andrea, well, what is it you need?" And at that point, I think if it wasn't for the fact that I had formed a close connection with the students in the building I would have left. You know, at that point I was livid. That you think this is telling me where I can find a good meal?

W: Insulting.

JM: I know several of you have mentioned the C-30 process and I think you need to explain to people that process is like. Because it is, it was a very subtle version of barriers and politics, and so on.

W: Absolutely.

JM: If you think about it. So I know ...

W: Absolutely. And with the C-30 process, it's a process by which school leaders are selected or appointed to a school. So, a superintendent could send you to the school, you could be offered a position in the school, but in 
order to be appointed to the school you have to go through the process.

JM: Appointed and be paid. (Inaudible)

W: (Laughter) Yes, exactly, right.

W2: That's right.

$\mathrm{W}$ : And there are levels to the C-30 process. It's meant to be a collaborative process. It is meant to be a process by which everyone comes to the table and they select a candidate that they feel is best for the school.

When I first started as a school leader the $\mathrm{C}-30$ process included the school boards. First you got an interview at the school level. No, first you met with the community where the parents were at the table, and usually in the school. Then you had to meet with the principal at that level. And then you met with the superintendent. And then after the superintendent you went before the school board.

Well, when the school boards changed over to community education councils the school board was no longer a part of the C-30 process. But it was designed, again, to be a collaborative process in that the parents could have a greater role in who becomes the principal for the school, a greater say. However, when I was trying to be a school leader it was very clear that the superintendent and the deputy superintendent, they were the ones at the helm of the C-30 process.

You could be the best principal or you could be the worst principal, if the superintendent wanted you to have that job you stayed there. It was not such a collaborative process. Now I think it may be more collaborative, but what I went through, it really wasn't very collaborative. It depends on where you are. And people got positions, for example, I know of schools, people knew they were going to get the school.

W2: Yes.

W: They knew they were going to get the position and so it was quiet talk amongst the African Americans, "Ah, don't even bother to apply to the school because you know you're not going to get that school. That school is for so-and-so or that school is for someone else." You knew you weren't going to get it. When eventually they did away with this policy that you couldn't get the job that you applied for as an interim acting, you couldn't be appointed to that position it really didn't change a lot.

People still knew who was going to be the school leader of the school. So, you almost had to wait it out. You were waiting for people to retire or almost pass away before you could get a position.

W2: (Overlap) That's true.

W3: (Overlap) That's true.

W: And for African Americans, both males and females, it was unfortunate because we knew, don't even look in certain parts of the district because you may not get that job. And if you were African American, if they wanted to put a token there you might be the assistant principal, but you were not going to be the principal.

\section{W2: Never.}

\section{W3: Absolutely.}

$\mathrm{W}$ : So, that was a very interesting process. When we look at school districts, and in reflecting on my role as a school leader, I know that there are systems designed for power and whoever knows the system best, and you can sit with those who have power in that system, you have a little power too. So, there's a little power and there's a little authority. And sometimes you get one and sometimes you get the other, but you almost never get both if you're African American. (Laughter)

JM: Anybody else?

W2: And when you're talking about succession planning and the phase with the C-30 ...

(Background Conversation)

GTB: That's very well said, Michelle, as you were speaking, I thought about something where I was a political pawn in getting an assistant principal position. So there was a gentleman, he was an assistant principal at a high school, and he knew he was going to get the principal's position. Well, at the Level Two they brought in a female, a Jewish female to become the principal. All of a sudden, his position goes up. I'm like why is his position being posted? And when they went to put an interim in, they put me in as the interim and he had to be booted out.

I was totally floored myself after I thought about it. Because I said, hum, that's almost the reverse. However, I would never become principal of that school because it was on the North Side. I became the assistant principal and I was the pawn they used. So it wasn't like, "Hey, we like her. Look, just put her there. You'll be principal 
and you just do what you've got to do.

Once her position is posted to have someone put in permanently, you can flip the script. Get rid of her and get somebody else you want."

\section{$\mathrm{W}$ : That's right.}

GTB: So, we're not only just not able to get those positions, but were used by other people in political ways. I did want to talk about the politics of not just racism, but ageism. Because when the leadership at the Department of Education changed and there were millennials who were brought in.

W: Oh.

W2: Yes, yes, that's right.

GTB: Who knew everything about anything. And I had the opportunity to work downtown. Director of School Reform, Director of School Equality. And I think maybe once at a lunch meeting we were having, someone said, who had been a teacher one year and was now working downtown, that he should be a superintendent. (Laughter) Well, I think my head exploded and I said, "Let me tell you what it takes to be ..."

And I think I went through my whole resume, Michelle's resume, Beverly's resume, Dr. Coppin's resume to say, “This is what you must do so don't think you can slide in here as just coming out of undergraduate school with a Bachelor's Degree and a half year of experience at central office and do what you think that we've been able to do all these years. Won't happen." And I proceeded to get up from the table and go back to my cubicle. (Laughter) I'm saying the brashness of millennials was another thing.

And the lopsidedness of, there may have been ten percent educators down at central office and 90 percent, I don't even know who those people were. Yes, because they're half gone now. But ageism and racism was crazy at that time when we had a change of the leadership of the city and of the Department of Education.

JM: And just to go back.

SH: I just want to say one thing.

JM: Oh, go ahead. Because I was going to go to you.

SH: Oh, lord. One of the things I do recall is during the whole process of going in for the interviews and so forth for principalship, there was a school board member who happened to be a white female who objected to me getting the assignment at PS 98 and her reasoning was that I did not have enough experience.

W2: Oh.

SH:Now there were two other people who were being appointed to two other schools in the same district who had less experience than I did and she thought that they were just fine. So, it's not only just the males, but the racism card is carried by both genders. And it was just quite interesting. And there became a little bickering on the school board itself and it was a white male member who said, "No, Miss Huggins has earned the right way. She earned her way to get this position."

So again, people are not looking at the quality of what a person has to bring to the table and it just kind of fits in with what you were just saying also, Gerry, about the millennial attitude that they have now.

JM: So what makes you, as an African American female, since you started that, what makes you uniquely qualified to be a school district leader? And we'll go around the table.

SH: I think for me, I had to know who I am and what I believe in, what my philosophy is. And I really believe that to be a teacher it's a calling, and to be a principal, it's a calling. Because you put in so much time, as our sister over there was saying, that she spent the weekend in her building and so forth. It's not something that you go in at 7:30 and leave when the children leave. You're constantly thinking about the work and what is before you.

I know for me, I got pushback from the union. In my particular case, if I can be so honest, my school did well. And it wasn't so much because of the quality of the educators or teachers in the building, it's because these children were so well prepared at home. They had life's experiences, they were travelling, and they were in different programs so when they came to school they just kind of zipped through the work.

My challenge was to push the envelope and say, "I'm not satisfied with these children just giving us answers." And so, I brought in other programs. I brought in the arts, which was not being, the money wasn't being spent on that at the time. I believed in physical education because I also know that children learn in different ways.

And I also had to bring in this respect for all cultures. Because we had children who were being bussed into my school and they were coming from South Jamaica. They started on the bus at seven o'clock in the morning to get to the school. And some of them came off the bus, you could see, you know, they were sleepy, they were tired. They had been on the bus for such a long time.

And I had to really impress upon my staff to have empathy for these children because they were coming a long 
ways and to understand that their parents wanted what they thought was best for their children, and to respect them and not to dismiss them.

And what I did see also was teachers who did not necessarily appreciate the God given talent of these other students because they did not live in the community. And to this day, I just recently went to a celebration of two former students who are African American. One graduated from college, from Syracuse, and the other one just graduated from high school and she's going to NYU. So I was really excited. I said, "Oh, that's my alumnae." Her parents worked really hard and diligently for the children to get the best of education. The parents did everything they could to make sure their children got exposed to things.

So, for me as an African American in a community that was so prejudice it was important for me to have a thick skin and not really show what I was really thinking. Because as I told one person, "If they really knew what I was thinking they'd get off the planet." You know? But the fact of the matter was that I never let anybody see when they were getting under my skin.

And to go back to another point, the men. I had some so-called want to be confrontations with the male fathers. They thought they could come up to me and intimidate me, but they didn't realize that I didn't realize that that was what I was supposed to feel, intimidation. And so, I would stand up to them and very quietly look them straight in their eyes and talk straight to them in this very controlled voice. And in one case a man who was even taller than me backed up because he didn't know what was going to come. (Laughs)

So my experiences although may have been varied from my esteemed colleagues here, there were those little times or incidents that really caused, if I didn't handle it in the right way, could have exploded into much more and it wasn't necessary. Yes.

JM: Miss Glenn, what made you uniquely qualified to be a school leader?

PG: Well, I had one answer, but now I have another. I think what really made me different or different in that school at the time is that once I entered and it was official I wanted a family. So, my whole basis of education in that community was to establish a family atmosphere. And I wanted that from the kitchen staff all the way up. From the kitchen to me, I didn't want anybody to feel they could never come to me.

My children were called "my babies." Everybody in that school knew you're my baby. I could be angry with you at what you did, but I didn't not like you. So I wanted my parents, when they had issues they would come in and talk about those things. Male and female. Staff, male. You're not going to do anything for my babies if you come into the school and your mind is someplace else. So, I need you to be able to come in and feel free to discuss with me or someone else, just like when they say you have a problem with the union, you don't have to take your school union rep, you can take somebody else with you.

I think forming that sense of family and community where the children knew it was safe, where the parents knew it was safe, where they could come and ask or they'd say, "Miss Glenn, I can't do this" or "Miss Glenn, can you do that?" "Yes, yes, we'll work it out. You know, whatever. Whatever you want, we'll work it out. As long as it's legal I'm good." (Laughter) And that's how we would roll in the building.

I think the children, they just wanted to learn more. The teachers learn more. If you met the babies where they were, as opposed to always saying, "Well, they should be able to ..." Well, some of them can't. Some of them didn't get that exposure. Some of them came from such diverse households that it would blow your mind. What was great for me in my home and the way my mom and grandma raised me, that's not where these babies came.

So, you had to be able to show them that in spite of anything that's happening in their home you're good. You're good here with me. If you need to sit in my office all day just to get your life together and Miss Glenn sits down and talks to you, that could be a teacher, that could be a parent, if you need a moment then say you need a moment. Because my kids, you know a kid can tell in a minute if you're not right that day. And that's when they get you. (Laughter) They do. They can read you. Children read you just like you're children.

W: Absolutely.

PG: So, if they know that you're the person, the go to person, that you're going to love them in spite of what they might have done, or what happened outside, or whatever, as long as they felt safe I think that's what made me different in that school. That's not the way it was always handled. Yes, the school was safe, but you know, you had to know, you could come to the custodian, you could go to that kitchen and those ladies in the kitchen will listen to you, and feed you, and help you out, and the custodian is going to hold your hand and walk you over here.

You know, if the crossing guard was out, then I was the crossing guard. You know, you have to show that you're going to do every single job in that building regardless of your title. It didn't matter to me. They would 
say, "Oh, such and such didn't show up." "Okay, let's do this." "Well, why are you sweeping the floor?" "Because it's my job. This is my job." And as long as you demonstrate that there's nothing too small for you to do then everybody's on-board.

When I needed problems or somebody got sick, figure out how you're going to cover the class. I don't care you do it, just come and tell me your solution. I'm not going to be the one that's always going to have the solution. You have to show me how you fixed it because that's how I got where I am. I had to show people how I fixed it. So, that's how it worked for me.

JM: Miss Brown?

GTB: Yes, I was going to say, you said, “How am I uniquely qualified?” Because I'm me. Okay. Let me tell you who me is. (Laughs) And I thought about it when I'm thinking about my life's experiences. When I describe myself I say, "I'm a Christian, African, wife, mother, grandmother who was reared by parents from segregated South Carolina, but cut my teeth here politically and knowledge-wise at the feet of Black Panther Party and Malcolm X."

So, that's a big picture of who I am. And that experience includes coming from a line of educators in the South. My aunt, I remember her telling me, there was no union so when you were sick you actually physically paid the person that substituted for you. I said, "What do you mean by that?" She said, "You would take cash in the next day and pay that person." She said, "So I went in the classroom and I'd be writing on the board and I'd turn and throw up, and get back, and write on the board again. Because we don't take days off when we're sick, Gerry." So that is part of the stock and the stamina.

I recently went to The Smithsonian African American Museum for History and Culture in Washington, the museum, because that's the only museum for me now. And it just made me think of my experiences. There's a big display about 1968, when you and I were in high school together, that just made me think of when I walked in as a high school principal or when I walked in as a guidance counselor what I bring from my life that could be beneficial from the children all the way to the kitchen, all the way to the parents and the community. What can you contribute that will make this a better place that only you bring to the table?

My first time being recognized by the community I got a plaque and they said, "You know, before you became this principal at this high school the children would be dismissed and they would run across our yards and do all kinds of despicable things in their yards on the way home." They said, "Those children come out the building and they walk down the street. They're a little loud, but no one's destroying our property. No one's, you know, messing with our stuff. There's something about the culture that's changing because of you." So, those kinds of things are things that you think about.

Having had the other experience, I thought about it when you were speaking, I was one of two black administrators in Long Island at a school district that had a five percent black population. So yes, that's a whole other side of the coin. (Laughs) So to function in that, also to bring that same life experience, I still bring the same me to the table wherever I go. And I remember after the interview, which had 30 people at it at their Level One, someone said, "You seem so relaxed." I said, "You know what? That's who I bring to the table."

I had a job anyway, but I remember sitting back and crossing my legs and saying, "You have to accept this package the way it is with the life experiences from behind me and who I bring to myself." But I will say also, I did have to find support and connectedness somewhere. And I guess we called our group The Underground Railroad. (Laughs) A group of black females who meet often. Coffee, tea, or wine, whatever. The experience may be to share our experience. Because you can't go through that alone.

Whether you're in the South Side school or North Side school you can't go through it alone. So, you get this group that just forms. And I don't think we did it on purpose. It happened out of our conditions. Someone had a bad condition, they talked to me. I said, "You bring Beverly in. Oh, you need to come Michelle." The Underground Railroad still runs because we need it help all of us feel free to be who we are in this environment as black women in education.

JM: All of you are retired. What has happened since you retired? Have other black females taken your place? If so, how? If not, why?

We'll start with Andrea.

AL: I have not retired. I retired from New York City. And other black females have taken my place because I was asked who did I want to lead the school when I left? And of course, I wasn't going to say someone else. I chose who I thought at the time was a qualified leader.

And just as someone gave me the opportunity, I wanted to make sure that that person had the opportunity. It's interesting, I now work in New Jersey and it's a different state, same thing. You know? It doesn't change 
because you go from one state to the next.

I think it can be in some instances even worse.

The segregation that exists, even worse in New Jersey. Because New Jersey is a state with ... It is actually one of the wealthiest states in the United States so it has severe pockets of affluence. So, when I go into the school my job is now to evaluate schools. And when I go into a school they see the name before they see the face. And then when I walk into the building they're sort of taken aback. Right? And I can tell by the demeanor. It's a whole different demeanor because now they have to sort of listen to me. You know? So it's like, "Oh, you know, what can I do to help you? Where did you say you were from?"

You know, sort of I've got to give my background.

So to answer your question, our place has been taken over. Now we have other women of color that have stepped into our place. I think it is a little, I'm not going to say easier, but we are definitely increased in numbers as the years have changed. I think it now has become our, I'm going to say obligation, for lack of another word at this time, to make sure that the women who have taken our place are successful. So, that they can have those conversations about what our experiences were and how can we help them overcome the challenges that they are now facing?

The end goal is that children will succeed. I didn't work for a year, I traveled the world for a year and then someone called to me asked me if I would help them with their district. So, that it sort of morphed into something else after that. But it is my passion to make sure that the children who are in these schools have opportunities to become educators, lawyers, doctors, whatever they chose, because we have embraced them as a family. Right? That we have made sure that the children in our school have those experiences that, I think you talked about, they go away, they travel, they do everything.

I made sure that the students in my school had those experiences. We took them to Europe. We took them to a restaurant just to have dinner that wasn't MacDonald's because it was a different experience for them. And I think that's what makes us uniquely qualified. And I don't want to speak for everyone, but I think we all realize as African American women that our children, our students don't have those experiences and it's up to us to give them those experiences so when they do enter those post-secondary educational institutions that they're taken aback by what their classmates experienced or they don't have that fortitude to go on and continue given the fact that they didn't have those experiences.

JM: And particularly I would like Michelle and Sheila to talk about what happened to their district school after they retired. Because I know what happened with your district. (Laughter) Did an African American succeed you in District 27 ?

MLB: No, no, they didn't, but I was asked also who did I think would be able to succeed? And I could not come up with anyone so I actually delayed my retirement for a year so that I could go around, and as I was looking at schools, looking to see which principal I thought could take the helm of my school district. District 27 is a very challenging school district. It has quiet issues.

On the surface you don't know, but I grew up in the district. You see, I lived in my district. I used to run home, I was a lot more agile in those years, and I would run home from my school during lunch, put the laundry in, start dinner, and go run back to school and be on time. All of my positions were in the district so I understood the district, I knew the district. And because I started to come out of the school and into the community people knew me. I understood. I talked to people.

I knew what the district needed and so I took whoever was going to be at the helm of District 27 very, very seriously. And it didn't work, in terms of it would have been nice if an African American male or female would have been able to take that position only because I really felt that there had not been in District 27 African Americans who were at the helm who stayed there.

We had a superintendent in previous years and she brought her African American deputy superintendent along. And I have to tell you what the district and the community did to her was absolutely appalling. I couldn't even go to the school board meetings anymore because it was too much for me to watch the yelling and the screaming. And I used to watch it and think, oh, my god, how could she just sit there through all of this. But those are some of things that we had to go through.

But no, there is a white superintendent of the district now. And while I could have probably, you know, and she may be a decent person, and that's not what my statements are going to be about, when they restructured the district she brought a white deputy, like they're serving like deputies, along with her. And that is what I took exception. So you know, I'm retired.

I have no say, but the thing that I did for years on a very conscientious level, I used that C-30 process like 
everybody else used that C-30 process. And District 27 started out, when I started out in 1982, '83 with 38 schools.

When I retired, there were 49 schools three years ago in District 27 and almost half of them are principals of color to some degree because I felt it was time to put African Americans, and Hispanics, and people from South Asia in some of these schools, and that's what I started to do. So, I positioned people so that they can then position themselves, even if not to be the superintendent of the district, but to be superintendent somewhere else. And I was very happy about that.

W: That's the point.

W2: Congratulations.

JM: And what happened to you, Miss Huggins, in your school? (Laughter) You were the first African American principal for 20 years. You retired and who came?

SH: Well, it was 23 years.

JM: I'm sorry, 23. (Laughter)

SH: I have all the grey hair to show it. Going back to the hiring process, District 26 used to get hundreds of applications for a position as principal in the district. Interestingly enough, nine of us retired the same year in 2015 and, as they say, the pickings were slim. And they eventually, it took forever, this person had to vetted and it didn't happen until, I guess, the end of July.

So, I never spoke to this person personally, but they did hire an Asian American to the principalship. Which is fine because you have Asian families moving into the community and it's representative and it's a little dig for that community who were so anti-Asian population. But the thing that has become a problem is that she did not have administrative experience. She had never been an AP. She had been a coach. She had been a curriculum writer, but that day to day experience.

I was an AP before I became a principal. I was mentored. I saw how things operated. I understood that there were some blockades that you had to overcome and anticipate them. She did not have that. And so, the very first day of school the police were called in because there was a parent that was ranting and raving at her. That was never seen when I was the principal. And from what I understand, you know, the school has a very different tone and people are miserable. And I think it goes back to something, again, my colleagues were talking about.

The school was part of what I considered my family and they were my children, the teachers were my children, too, to some degree. And there was nothing that I would hesitate to do for the school. I, too, was in the cafeteria. I was a school aid when we couldn't hire the school aid. I was even the phys ed teacher one time because we couldn't get a substitute teacher. Whatever it took, I was there. My door was always open.

This person has the door closed because she's scared. She doesn't know what to do and how to handle the situation. I built up a community of people, workers, from the kitchen to school aids, to the custodial staff, my secretaries, my support staff such as the guidance counselor, the psychologist, and the school nurse. They all rallied and went above and beyond their contractual agreements for me because they knew that I, too, would get my hands dirty. That I was out there and that I appreciated them and valued them.

I mean, I literally have had people that were crying because I decided to call it quits. And now they're crying because there's a person there now who is only concerned about the data, concerned about what is the superintendent going to say, doesn't want any parent to be angry with her. And also, the teachers she just kind of throws over to the side. And we all know that we have staff members, the good, the bad, and the ugly, the bottom, the middle, and the top. And even with the bottom ones, you have to, if there's something salvageable you have to make them also know that they're important to the organization and get the best out of them until, you know, they're going to retire or they take another route of some sort.

But this particular person has become like a hatchet person. Not listening to ... Well, she listens more to parents. And we all know that parents have a certain perspective and it's now always accurate, you know. So, it's been a tumultuous time at the school at this particular point. And it saddens me because I was there for 23 years and I built up a community and it was a family, and everybody worked hard together.

And then the other thing was the school was granted, conferred with the Blue Ribbon Award. She's taking the credit, but it was my data that got the school the Blue Ribbon. (Laughter) And here's another terms of insensitivity, I was invited to the graduation, the final assembly, and this was in 2016, and she had me sitting in the audience. She didn't even have me up on the stage. 
She didn't have me address the kids, anything, but I had gone up to the classroom and spoken to the kids and got a warm welcome from the children.

But it's that kind of disconnect that she has with people. And I think, as it's been said, you have to have a connection with folks. You'll get the best bang for the buck there. You know?

BB: And the reason why the person to your right is nodding up and down only because I was your superintendent. (Laughter) She's nodding. And Miss Glenn, your successor was an African American, but ...

JM: She's just like her successor, she's just black. (Laughter) So is it fair to say that everyone sitting at this table was successful? And you made changes? And the school benefitted and the kids benefitted, but the district and the culture just considered you something unique.

And the district and the people who hire the school leaders that came after you, there was no change in culture. There was no support for these people. They did not assess their performance or give them guidance. Are those statements fair?

W: Um hum. (Affirmative)

JM: And is it just in your case or did you see it in other cases as well? Because that's what we are trying to say here and I think that ...

SH: As I said earlier, there were nine of us who retired the same year and I'm hearing this kind of drama is occurring in some of the other schools as well. One of the reasons why I retired, even that I did it for 23 years, I loved what I did. I had joy with it. It was fun. The kids would come up to me, you know, we would interact. I sometimes knew the children better than the teachers and I would go to them and ask them about, "Well, how is so and so doing?" or "What's going on?" Or they would come to me.

That is not the case and we're hearing about this kind of anger and disconnect in a number of the schools in the district that I was in. So, it wasn't just my school. And I think a lot of it has to do with the lack of the experience. I brought to the table, I was a parent so I understood how the parent felt on the other side of the table. I'm a grandparent. I understand what that's like. You have people who are coming in completely disconnected from understanding that the person that's before you really doesn't want to be adversarial.

In some cases, they're desperate, or they're scared, or there's something else that's going on with them. I'll be very frank with you, from what I'm hearing, people are just puppets coming from downtown and just repeating the mantra and there's not room for individual thought and innovation. And everybody's like a cookie cutter now. And that's a major reason why I left because it was no longer fun.

PG: I think part of the problem is we're old school administrators and we come with the experience, and knowledge, and backbone. And these newbies that are coming in drinking the Kool-Aid and being told they can do whatever they want to do, they're autonomous is not how you handle something. You have to sit down, as Sheila said, and let people know, "Been there, done that. I understand. I got you. I know how to handle this." And I think these people come in and they just want to repeat what they've been told and they think it works like that. The first thing people have to understand as an administrator, black, white, green, purple, is that you're dealing with people and not numbers.

W: Yes.

PG: And until they get a grip that the people they're working for, because we're working for these children and these parents, they're not working for us, we're working for them, our job is to ensure their success. Our job is to be a positive role model for them so that these children can see that there are professional black men, professional black women as principals, and administrators, and superintendents, and chancellors, and everything. That's our job. So we're working for them, but until that connection is made that you have issue and you're bringing that to me, you're the most important person in this office right now.

As long as the school is not on fire, nobody's bleeding, whatever you have to say, I'm listening to you and my door is shut. When you leave, my door is always open. But now, the people that take our positions, the door is closed. There's this disconnect with the staff. They feel they're up here with a crown and all of these people down here are pee-ons. And whatever I say goes and the children are just a by-product of what goes on. They're not working for the babies. They're not. They're worrying about the data.

So okay, this kid does well, this teacher does this. Well, that's not how it goes. They're children and children come first. And if that's what the goal is, that children come first, be it an Asian child, a white child, I don't care what. It could be a Martian. If they can speak English, I'm going to teach them. I used to have a teacher that worked next door to me and she would say, "Glenn, I could teach a dog to read." You know what? I believe she could. (Laughter) 
If she really figured out how to do it. No, no, that's how serious she was about her job. And we fought all the time, but at the end of the day I respected her for that because that's how passionate she was about her job.

And unless you have that passion about your job and you know who you are and what you bring to the table.

\section{W: Right.}

PG: And your vision is for success, be it Blue Ribbon or no ribbon. Because at the end of the day most of us don't get ribbons. But you know and you could put your head down at night you did everything humanly possible that you were supposed to do for your babies. And that's all that matters. So, speaking to what Beverly said, my successor was black, is black, but she's like this chick that took over her school. (Laughter)

W: Can I just chime in on the successor thing?

PG: Yes.

W: Because I think I have a different kind of story. And I have a different mindset about today's leaders as well, a little bit. (Inaudible) A quote, "The secret of leadership is not to think of your position ..." Oh, my god, here I am tripping over it. "The secret of leadership is to think of your position as an opportunity to serve, not as a trumpet call to self-importance." So, someone gave me this little booklet when I became a principal, and I used to read it every day to make myself remember that I was there to serve.

I am currently on the Community Education Counsel, which is the new community board for New York City, and it's not a place, you don't have a lot of power, but your presence there can make a difference. And I have found, this is so interesting to me, that there are principals who are coming, now this is a volunteer position, coming to me, "You know what? Can you do a walk-through with me in my school?" "You know what? Can you help me out with such and such?"

So maybe it's not the successor they come to. Because, to be honest, as a principal my successor was a black male who happened to be an assistant principal of mine, but was not the person that I said should have the position. And it proved to be the right thing that I said. You know how someone who says, "I'm going to undo what someone else did", is now running the country? So, in some cases people want to undo what you did. I'm just being honest. Let's just put it out there. So, that was my situation as a principal.

As a superintendent I picked my successor. She and I would talk together, "Look, I'm getting ready to retire. Bla, bla, bla. You're going to go interview." She goes and interviews and she's so good, they put her in, somebody else retired and they put her in that position first. (Laughter)

W2: Wow.

W: So she got a job and I was like, "Well, who's going to replace me?"

W2: Yes.

W: I was replaced by an Italian gentleman who I knew from working with him in the past. And as things shifted he eventually had to move on and was replaced by a black female. So I mean, even when you do the best planning that you want sometimes, I mean, it worked out wonderfully for her. She did become a superintendent, she still is a superintendent and she does a great job. But I just had that feeling about sometimes people just want to undo what you do.

W2: Yes, yes.

W: To discredit your work and your worth.

W2: Yes, yes.

W3: Yes, yes.

W: And you say, "Why are you doing that?" I started smaller learning communities, I did this, I did that. Get that out. That's gone.

W2: Rather than build on it.

W3: Yes.

W: Exactly, exactly.

JM: And when we are talking I thought about what you have brought to the table that they have not captured. The ethics of caring.

W: Yes.

JM: Everyone here talked about caring. The experiences that you have had as living in the community.

W2: (Overlap) That's right.

JM: Being a person of color. Understanding what the youngsters, and the parents, and even the teachers, and we haven't spoken about the teachers, that's a subject of another conversation. And the ability to communicate with the people that you work with, not only in the school, but outside of the school. And finally, that even though all of those other things are important, you hold yourselves personally accountable for seeing that these youngsters do succeed. So it's not the only thing, it is part of the way you think, but it is extremely important that you not only can relate, but you can improve instruction and it's not a separate area. 


\section{W: Can I comment on that?}

JM: Yes.

W: You know, one of the things that we do is we say things publicly and we say things privately. And when you do not set goals for your school or the district, the same public goals have to be the private goals. And then sometimes you have those private private goals such as race and gender that you need to deal with because of who you are. At one point, I became a single mother and I know that there were people who spoke to me because they didn't understand, "How did you finish school? How did you do this? How did you make it happen?"

So, you can take them to the side, and I absolutely agree with you, it is sometimes other teachers. And I would say, "You can do it. This is what I want you to do and then get back to me. You can call me because we have that interest there." You talk about the ethics of caring? That interest that we want everyone to succeed. We want the kitchen workers to succeed, when they look at you and smile.

When we talk about us being uniquely qualified, yes, I believe I was uniquely qualified, as I do everyone sitting at this table. Because when we walked into buildings people knew who we were.

The kids paid attention. This is someone important. They may never see anyone important who looked like you that they would know again. But they know from the moment you walk in.

Other folks sometimes, sometimes people non-black, African Americans, they may not have that same feeling, not that they don't care, but they don't care like you. You know you want that kid to be your doctor, to be your lawyer, to be your whatever, to be your teacher. And so, you put the effort into it because your private self said, "I care." Your public self says, "I care." And then your actions show that you care.

W2: Yes.

W3: Absolutely.

W: And so all of that came together. And when you walk in you look so beautiful, and the kids compliment you, and they smile. And when teachers, they pay attention. And when your principals feel good that you're there. When they call you because they know you have something to share that is worthwhile. And that was worthwhile for me. And so, yes, I think we're all uniquely qualified. And yes, I really hope that all of our school districts have people of color that stay at the helm because our children need it.

W2: Great, great.

\section{(Background Conversation)}

JM: What strategies, both personal and professional, and yes, political, did you utilize to help you become an educational leader, not only within the school, but also at the district level as well? Because our conversation does include educational leadership at both the school and the district level.

GTB: Right, I remember wanting, well, yes, kind of wanting to become a leader, an educational leader because I saw two black women who were just, I was enamored with them. I admired them so much. And one of them is sitting here. It happens to be Dr. Coppin, she didn't even know that. (Laughter) Oh, yes, here we go. So, when I was a guidance counselor my superintendent would tell the principals every year we honored one person from the school or two people from a school who had done an outstanding job.

\section{JM: (Overlap) Correct.}

GTB: I didn't even think the superintendent knew my name. She had come to the graduation and during the graduation ... What happened during the school year, a music teacher took a sabbatical and there was nobody to play for the chorus. So I say to the principal, "Hey, I play the piano." So, I played a little piano and then we had a chorus and during the superintendent's speech she said, "You know, what kind of metal we're made of. Look at this. Today we have a guidance counselor, Gerry Taylor-Brown, who's playing." I said, "Oh, my god, she said my name. The superintendent."

Then we go to be honored and I'm one of the people selected. Each principal got up and spoke about the person that they were honoring. And I turned to my principal and said, "You know what? And this is going to sound weird, they're as stupid as me. I could do that." She said, "I know you can, so what are you going to do?" I said, "I'm going to apply for Bank Street College."

W: Oh.

GTB: And I did. And I got in. (Laughs) And the rest is history. No. But the rest is that I saw an example of what I could do. I saw a principal that was leading the school that was in a difficult situation and a 
superintendent who came around and gave direct guidance to the principal, and walked the school building with her and with us, and knew us, and knew the kids. And I was like, this is what I could do. So thank you, Dr. Coppin, for catapulting me (Laughs) into educational leadership. You and Miss Beck. Because had I not seen your example I would never have gone for the advanced degree.

Because let me tell you, being a guidance counselor is a nice easy seat. You get an office, you have a phone. You can go to the bathroom whenever you want. (Laughs) You see children as you arrange the time. You're not given a program to teach, but you see children as you're given time. So, it's an easy place to be. You know what? I do this well. Let me just ride this out. But seeing you and seeing Miss Beck made me think I can't just stay here, I have to move on.

And so, I know everyone here can say that we stand on the shoulders of those who have come before us. You have provided awesome shoulders, as have other black women in my life. So, thank you very much.

JM: Thank you. I'm totally embarrassed. (Laughter)

GTB: This is why this is being shown.

BB: Any other?

AL: So as I said, I started education as a second career. And the principal at the time was Dr. Percy Jenkins and he was an amazing leader.

If he said he wanted you to use a certain instructional strategy you did not understand, he went into your classroom and taught the class until it was crystal clear that these kids were important and you mastered. $\mathrm{He}$ was using mastery learning at the time and was very entrenched in mastery learning.

This gentleman put his heart and soul into making sure the kids in his school were learning and could succeed, so much so that he died doing, retired, died the next year sitting at his kitchen table still trying to develop an educational company. And so, I thought this just must be kismet that I came into education. We think about what we want to do in life and what is God's plan for us in life. And so, at that point I decided that this has to be the plan. Right. And so, standing on that gentleman's shoulders.

And then Ernest Logan became the principal after Dr. Jenkins passed away. And so, I had two wonderful mentors. To go back to the question that you asked about who replaces you and what do you learn from that person? To this day, I can pick up the phone and call Ernie and say, "You know, I need you to do a workshop over here in New Jersey because I have a group of principal leaders who could benefit from your knowledge and your skill. So, networking and pulling upon those skills, those are strategies that I like to use.

Usually I pull from people who look like me because I think we need to give them the opportunity to network when they have the skill sets to do so. So, I've had that opportunity. So, I use those strategies to network and to make sure that I'm providing important strategies, not only for teachers, but superintendents and other people in the district that can continue to grow and understand what's important for students.

JM: Anyone else? Well, thank you for that.

GTB: You're very welcome.

JM: So I'm thinking, you talked about all of the sacrifices that you had to make personally to make your schools successful and your leadership effective. What advice would you give to those who are coming into such positions today? I'm asking about how do you balance those things that you have to deal with personally, as well as politically, in terms of future education for yourselves. How do you do that? How do you help people to do that?

W: My father, he was an educator also. And he used to always say, you know, I would come home and I was so frustrated sometimes working with my classes, and he would say, "Find something about the children that you like. Find something about that child. That child has something. Even the worse child that you think is the worst child, they have something in them. Find it." I think I would suggest to people coming along, you have to find something of this career that you like.

What is it that speaks to your heart? What is it about the community or any community that you go into, who are your clients? Who are they going to be? And really know them. Bring your values and your set of beliefs with you. What do you value? Who are you? What are you about? And are you willing to go the distance? You know, this is hard work this education business. And I remember teachers taking off because their husbands were businessmen and they won a cruise or they were going on a cruise and they wanted a week off so they could either get married or go on the cruise in the middle of the school year.

And I would think are you kidding me? And I was just a teacher then. And I'm thinking this is a different kind of business. And even when I became a school leader I would say, "We need to be here." And so, I would say to people coming along you need to be present. You need to be in the moment. You need to be willing to extend yourself, not just at the job, at its location, but outside of its location. And it's just so many things that 
you can do. And know your craft.

You know, it's not enough to go home and turn on the television. You have to be willing to read. You have to be willing to attend those conferences. You know, are you willing to facilitate? You know, it was interesting, because when I was even deputy superintendent, I was the Deputy of Curriculum and Instruction, anyone could call me into their school. I felt like I was a master teacher so I will come in and show you how to do it. And I heard you say that. You would not say to me that I didn't know what I was doing. So, I would be willing to put myself out like that.

And I would say be willing to show people that you know how to teach and that you know how to lead. And honor your word. Be fair and honor your word. A lot of times we talk about dialogue. When you speak you need to speak honestly. If you don't have the answer don't say it. Just be quiet. And so, those are just some of the things I would say to people because those are the things that helped me.

W: And it sounds corny, but we're touching the future. We have such a tremendous opportunity to really impact on what's going to happen in years to come. And again, it's loving what you do. And as you said, valuing what you do. And it was always important to me, yes, like you said, to read, to network with other people, to hear what they were doing.

Wherever I went I was going into a school somewhere to see how things were being done. Because no one person has all the answers. You have to love this profession.

And it's not about the money because when I started teacher it certainly wasn't a lot of money. I remember when I was at PS 5. Here I am, a new teacher coming in and I was given a class of children who had been difficult in some of the other classes. So, they made this one class of 15 children. And they gave me a para who had an alcoholic problem. And I was all of 23, but I didn't know that I was supposed to be disgruntled about this. I saw it as something I would take on.

And by the middle of the year the cluster teachers were clamoring to go into my classroom. They said, "The kids are so wonderful. They're so loving." And I took that also as an administrator. I'm not going to go back over what everybody else has said. You said it so beautifully, but just really have to love what you do. I used to meditate before I went to work and I always wanted to make sure that I brought light, and wisdom, and joy into my environment wherever I was. Yes.

W: I think I would tell someone who was aspiring to be an administrator that you have to love adults, not children. You have to love adults and you have to think of those adults as the best class you are going to ever teach in your life. I had 200 staff members, 2,000 children, but I had to love each of those adults. And think back like, "Oh, so and so is acting like Tae Quon(?) used to act when I taught seventh grade, okay." (Laughter) Those kind of relationships.

I think that was a barrier for me. Because I was like, aren't these grown people? Don't they know what they're supposed to do? No, they don't. (Laughs) These are teachers, and cooks, and school safety agents, and paras, and guidance counselors who are looking to you to be that principal teacher in that building.

W2: That's right.

W: And take it up a notch. Those 84 principals were looking for me to be the principal's principal, I guess. You know, to be the superintendent or leading a district. I know Michelle has, you know, the same kind of experience with you as well. That you have to be that person that looks at those adults that you lead as your class and be able to mentor, coach, teach, lead, help them become better as grown people. And sometimes it involves helping them in their personal, as well as their professional life. You have to know them in and out like you would know a student sitting in your class. You know his parents, right? You know where he lived in the neighborhood.

Same thing about your teachers. So that's the difficult shift, I think. It's about the kids, but you are making the best adults so they can be the best adults for children.

W2: Well, I think that I loved every ...

W: No, I'm not saying that. I'm just saying that you have to really zone in. My best word of advice is to get a support network.

W2: (Overlap) Personal and professional.

W: You just cannot take on a leadership. Personal and professional. Whatever. Meditation, listen to music, go see your priest. (Laughs) Have the girlfriends in the Underground Railroad group. You need almost like fingers on a hand, at least five different points of support for you, in your own personal family, in your spiritual life, in your social life, in your emotional life. You need to cover all your bases because it's not easy.

Michelle, you said, it's not easy being an administrator and definitely not easy being an African American 58 
woman as an educational leader in this country. Maybe there's another country where it is.

JM: Say those five things again?

W: Oh, my gosh, did I say them again? (Laughter) Oh, no. In your spiritual life, in your social life, in your emotional life, in your professional life, and your personal life. Did I say that too? I forgot all five. (Laughs)

JM: Your hanging out life.

W: Your hanging out, that's right, your hanging out life. You must cover all your bases so that you can bring your full self to the table every day.

PG: I think that's really key because in my first, I want to say, ten years of being an educational leader I was immersed in the job 24/7.

W2: Yes.

PG: I picked my kids up, brought them back to office, sat them in the office while I did whatever, and then we still had to commute to New Jersey. And in retrospect, you can really burn out very quickly putting your all into that. So, on building on your five fingers, I think I would tell them to practice distributive leadership, is what I tell the principals now.

W: That's right.

PG: It's very important to realize that you are not the be all to end all. Don't think that much of yourself. But really have those people around you at the job where there is a lead teacher, your AP or a teacher that you see the skill and potential in, that you can help those people put that pie together, if you will, so that when you have your leadership team meetings it's not about you bringing people together to tell them what you want them to do, but listening to what they brought for that week, or that month, or however long it was. What do they bring to the table? What do they see as being some of the issues in the building?

And empowering them to have the ability to do that job with some guidance from you. "I'm going to empower you, but if you need assistance come back to me." It will free you up to have a personal life. We can't let this just consume us. And that's what we, as African American women, tend to do. Not only as leaders, educational leaders, but in our own families, right? They come to us, right? The children, whomever else, the nieces, the nephews, they all come to us to try to help them figure out their problems. Heavy is the hat that wears the crown.

W: That's true.

PG: So, you have to have that network. And sort of, we all, I think, have that network that we look to, that we complain to. To say, "Let's go out for drinks," you know, or, "Let's go wherever," you know, because we have to have that so we can vent.

W: I would say one thing to what, my advice would be people teach you what to do and what not to do. And as a good teacher you're taught to observe. As an administrator, you're taught to observe. As a parent, you're taught to observe. As a person in the world you're taught to observe. So, when you're given this job realize that no man is an island and you can't do it by yourself. You must have a support system.

If you don't have a friend then, you know, listen to your music, read the Bible. I knit. That's what keeps me going. You know? Like you said, your family looks to you. And I was raised by two strong black women so I am now the strong black woman of my family. But when you sit down and look at all of your experiences in life, and your principals that you had, and teachers that were with you, some of them were great and some of them sucked. And there's no other way to put it.

You have to discern what good qualities come and what you want to be or how you want to project yourself and you cannot do it all by yourself. You just cannot. And the person that thinks that is just a fool. You're just a fool. And you can't diagnose and prescribe your own self when you're sick. You can say, "These are my symptoms," but you can't go out and fix yourself. So you need to know, well, this person she did this and I like that, but I didn't like that.

And when we were talking about before, why destroy the foundation that was put in place from your predecessor? Okay, you walk in and you say, "Nah, I ain't feeling that," but then you're going to say, "Oh, I'm good with that," and you're going to build on it. And it's not to put you down. It's to say, "I see the light in that, I'm not so good with this right here. Get my group together, see what else we can do." When you can do that then you are an educator, then you are a professional. Then it's not all about me because it's never all about you.

At the end of the day it's never all about you. So, if that's the advice that you have to give somebody, they need quiet time, they need to sit down and meditate, talk to yourself, knit, sing, whatever, but you need that time. But 
you can sit down and say, "These are the good qualities that I'm going to embrace, personal and professional." Because you're going to take things from your home, and your family, and your friends. And then what you learn at work, you're going to pull from that and you'll process that, and that's what makes you.

And that's how you grow and become a great professional. So, that's the advice I would give somebody new. W2: You know, first of all, I appreciate, I'm going to take notes and then do this job again. (Laughter) Maybe I'll do a better job. Okay?

W3: That's great.

W2: No, I'll you, I'm going to do it a second time. I think I'll be a better superintendent. But nonetheless, one of the things that I think we might want to tell people coming along, and you may have said this, is to check your ego at the door.

W: Yes.

W: Yes.

W2: Because a lot of times we think I've arrived.

$\mathrm{W}$ : Yes.

W2: I could do it. Because a lot of times, and speaking specifically about African American women, we tend to think we could do it all because a lot has been placed on us.

W: That's right.

W2: You know, in my household I'm the eldest of eight. I've got seven of these guys. Some of them are professionals, even the professionals lean on me. I mean, I've got my kid. He leans on me from time to time. And I don't mind the lean, but the lean gets tiring.

W: Yes, it does.

$\mathrm{W}$ : Oh, yes.

W2:And we need to understand we get weary, we get tired, and other people could shine too. And so, we try to lead a path so other people can get on. And someone said something about the light? Okay, you want other people to be in the light also.

W: Right.

W2: You don't always have to be in the light.

W: No.

W2:Sit back, let others delegate. Let other people do it and then you could sit back. As matter of fact, the less tired you are during the day, maybe that's the best day you did the best job. (Laughter)

GTB: But it takes seasoning to see this. It was my fifth year as principal.

W: Yes.

GTB: And I had my cabinet, and the cabinet, I said, "Listen to this, I'm not coming here at 6:30 anymore. As a matter of fact, I think I'll come at eight o'clock. As a matter of fact, here's a cell phone, you keep it overnight and when I come here it better not be screwed up, that's all I'm saying." Whatever, the school better be ... I didn't say screwed up, but they knew I meant don't mess up. (Laughs)

W: Right.

GTB: But I stopped coming in at 6:30 in the morning. But it took five years (Laughs) for me not to come in early. And it really took everything in me to stay home and not come in until eight o'clock. Because I'm saying, "Oh, my god," my head is still going, "I wonder if the kids got in for the zero period? I wonder if school safety is okay? Did they do the scanning?" All of these things are just running in your head all day, but it's okay. And you know what? They did a good job. Sometimes. Sometimes it was a little messy, but by and large, they did a good job. And I liked the fact that the students looked towards them.

W: Right.,

GTB: The assistant principal is like, "Oh, I'm going to talk to Miss A. I'm going to talk to Miss P. I'm going to talk to so and so. I don't have to run around to see Miss Brown, the principal, I can rely on these other people to ensure that I'm safe and I'm learning in this environment and it's not just the principal. And of course, after five years I left and became a superintendent. (Laughs) That's when you get it down, right? They skootch you up to another level. But I think I'll come back and do the job, too, thank you.

JM: We have a couple of replacements for the vacancies that we had. (Laughter) And then, finally, we said we'd talk about all of those personal and professional attributes that you brought to the table and to the position. But the final question is what did you do that helped students improve in their academic achievement? In other words, yes, no matter what happens we still have to talk about data and the hard facts of running a school.

W: Or district.

JM: Or district, that's right. So how can we say that, yes, you made significant improvement in your school or district by looking at data and what data would you choose to do that? 
MLB: You know, the late Dr. Beverly Hall, former superintendent in Queens and I believe in Atlanta.

W: (Overlap) Atlanta.

MLB: She had an expression and would say, "People respect what you inspect." And I always, I mean, I never forgot that. I believe that as a school leader or district leader you have to be a master teacher so you've got to know your craft. To me, visiting schools and looking at the curriculum and the instruction of those schools and holding people accountable is key.

You have to know the data of the schools, you have to know the data of your district. You have to be able to talk about it. You have to be able to talk about it often.

And then you have to go in and show people how they need to do it and then you're coming.

Show them what to do and then say to them, "I'm going to come back at such and such a time," because that's holding them accountable so that they can have time to make some improvements. I just think just every day getting up and going into the job, it's not enough. You have to know what are you looking for? What is the priority? What are we living for? If we say we're living for the kids, and as you say about the student achievement, if you think that that's important then you have to inspect it all the time, regularly, and people have to know that that's what you're going to do. That's what I do, that's what I did.

JM: And did it.

MLB: Did. And when I retired, out of my 49 schools, take three of them off because they were early childhood schools, two were reward schools, state accountability, and I left 38 of them in good standing with the state the year that I retired. So, I know that we were moving in the right direction because I was an instructional leader and so I focused on that a lot and I spoke to it a lot. And that was my expectation, that your school was going to improve.

I remember being a principal and I would have the teachers come downstairs. I would call them over the loudspeaker, over the PA system because I knew that everybody knew what was on my, I guess my witch hunt that day. And I would have them come and bring the data from their class. And I wanted them to show me what they planned to do every six months in terms of moving the agenda for their students. Which books they were going to be reading, what kind of pre-test they were going to give, what kind of assessments they were going to give.

They were so upset, this is when I was interim acting also, maybe that's why I didn't get the job. (Laughter) But they were so upset they took it to their union, you know, to complain. But instead of the six months the union person asked me to bring it down a little bit more, to extend it, to give them some time. But I held them accountable. And it makes them feel good because it reminds them as to why they were working.

JM: Go.

AL: Well, the accountability is key. So, and empowering everyone to look at that data and giving them the professional development they need to understand the data story. So I can give you data, it doesn't necessarily mean you understand how to use the data. So, we had professional learning communities that occurred every week for three hours on a Wednesday. And we looked at data. We looked at data, we understood what the data said, and then what were we going to put into place to make sure the students were moving forward?

At the end of the marking period I called selected teachers down because I looked at the report cards, I looked at the failure rates, and those teachers had to explain to me why X percentage of those students failed their classes. And if they needed professional development, so they said, we tried to provide them with the professional development they needed to move forward.

Additionally, we looked at when we did our evaluations or observations, what's going on here? And at that point we were using Danielson(?). So, we looked at what were the domains that they were not proficient in and then gave them professional development to support that. Now after all of that if you couldn't move we moved you, but it wasn't upstairs, it was sort of out the door. And as my role as the executive director, it's key to make sure I know what those 36 schools that I'm supporting, what happens with them.

They get report cards every quarter, we do what we call cycle reviews. So, the school community has to present to us, myself and my team, the data. So, we look at climate and culture data, teacher attendance, student attendance, suspension rates, subgroup data. We look at failure rates on the benchmark assessments, they're assessed in New Jersey every quarter, if they have to at least get a 70 percent proficiency.

If they aren't hitting that standard what are they doing next? And then we make suggestions. Failure rate, graduation rate, ELA standards. So, they have to present this data to us and then we give them our suggestions about how they can ... We do look at the strengths and the challenges of the schools and then our 
recommendation on how they could move forward. Now we do follow through with them for those recommendations to see how they're moving their data until the next quarter.

So it's key to look at ... They use Park in New Jersey so we look at the Park data, as well as the climate and culture data and the school data.

GTB: I recently had an opportunity to visit someplace that I hadn't gone in a while. It happened to be your college.

When I was an Assistant Education Director for the Head Start Program, we were in this dilapidated building and we decided that we were going to move forward and try to get a campus childcare center and it happened to be at your college. Today that still stands. I think part of what we do and looking at our accomplishments is, number one, impact, but the second part is sustainability.

So, that's why I get heartbroken over leaving a school and going, "Oh, my god, now it's not where it was." But the campus childcare center is still at your college. We helped design that and that was in the " 80 s. Do you believe this? This was in the ' $80 \mathrm{~s}$. Some of the instructional things have changed, but to know that we went in and had an open classroom. Where children were before in a little self-contained classroom with teachers, it's this whole open plan with this big library in the middle with a cylinder where children could just go and casually read. And how many children have come through those doors and gone onto elementary school prepared than if they did not go to pre-K?

When I was in Long Island someone said, "Well, what impact did you make?" And I started writing down stuff. So this is the first time, I do have some sheets here. I did write some stuff down. That when I initially went there that the graduation rate was 88 percent, but when I left if was 90 percent. When I initially went there the Regent's diplomas were 46 percent, but when I left there it was 62 percent. This is not like, oh, my god, all the kids are getting Regent's diplomas, but we sure were moving in the right direction.

To be honest, as a high school principal I believed that my highest impact was on culture and climate where we had 300 suspensions down to a hundred and change by the time I left. Just the change in how you look at the behavior of these people coming through the door. But because they're 180 pounds and they're 5' 6 " they're still children. They're still babies. Those were my babies. They happen to be my babies. They happen to be age 14 to 21 .

W: They were big babies.

GTB: They were big babies, but they were my babies. (Laughter) So just thinking about that kind of thing. I always want to think about sustainability. What was I able to implement that people kept going for? And I'm telling you, when I went to your college I almost did cry. Because I was like, I don't believe this is still here. It's impossible. That was the ' $80 \mathrm{~s}$. So, I think that we need to hold people to that kind of standard. I mean, we're in a facility now, like, oh, my god, when was this building built and how long has it been here? Right? How long has it been here and what was the tradition that still continues in this environment that this building still stays here to this day and continues to grow?

So, that's what I think we need to try to pass onto the next generation. Like don't just start something to have it, but start something that you know is going to be beneficial to people and that you can see will be sustainable in the long run, and continue to be beneficial to people.

JM: Miss Glenn?

PG: Okay, so I'm thinking that historically my building had wonderful scores when I inherited it. And as I said before, it was a well-kept secret in the district. So, I really didn't walk into a place where the struggle was so serious. I had to learn to maintain and sustain it. However, when administration changed and the Bloombergs came in and you were told to teach this one curriculum to every child where one size fits all, that's when I saw things start to fall apart. In my school, every classroom was called "your house." What you do in your house is on you. Teach the kids, treat them right, don't do anything untoward to anybody, but if I need this paper over here to help you I'm going to give you this paper.

If I need you to sit over here and do this while they're doing that, you can do that. That's your house. You know your babies better than anybody else knows your babies. I found that when this new program of reading, and you had to do it at this time, you better do it with this group, and you have a certain amount of minutes to do this, when it became a business and not education it became disheartening.

So, I can say that when the school report cards came I had As, Bs, I think I had a C. The year before I retired I had an F. And as shocked as I was to get the F, I deserved it. And I think I deserved it because there was a part that we took for granted. You know, because we were good. And I think that we became a little too lax. Yes, I had all the data. I had the meetings, I had the groups. You name it, we did it. I brought everybody in. I did everything. You couldn't get me on a thing. She'll tell you, she was my boss. And when she called and told 62 
my assistant that we got an F they didn't want to tell me.

So, we knew we had to put on our big girl panties and tighten up and we did. And there was no argument. There was no pointing of fingers. There wasn't anything like that. It was like, all right, we screwed up. What are we going to do? This is a family. When family falls apart, when tragedy happens in family this is what you do. Nobody came to me and said, "Well, Miss Glenn, such and such ..." Go back to your room. You got the same F that everybody else got. Even if you were in kindergarten that F started in your room at some point and it's up here now.

So, when I left we were back in good standing and we had a B. That was because we put on our big girl panties and we did what we had to do. And when you recognize that you can fail and you don't stand there and go, "Woe is me," because that's life. And like I said, when tragedy happens in a family, the family comes together. So we came together. Did it mean that we had to go the extra mile? Did it mean that we had to push a little harder?

You know, I'm not saying there weren't tears. I'm not saying there weren't day where I didn't get the roots of my hair touched up and my nails were bitten off. (Laughter) I'm not going to tell you that. I'm not going to tell you that I didn't come to school in my sweatshirt and my jeans, you know, or my hat on my head pulled backwards and like... You do what you got to do.

But at the end of the day, my babies were happy. They didn't know we were upset. They knew something was wrong, but they didn't know how wrong it was. Because in a family, you know, we were told, "You speak when you're spoken to." The adults are talking about this over here, but you really don't know what's going on. So, that's how we handled it and they ended up fine. Nobody knew any different, except we did at the end. We knew what we had to do and we could congratulate ourselves.

And that's the best thing that I have to say about what I brought. And hiring men. I think it was important to hire men in my building. And I found every black man that I could find that was qualified. I'm going to say just men, period. Because my babies needed to see positive role models, black and white. My custodians sat in on meetings. They were white and black. "I want you to be able to talk to this boy."

We had Etiquette Day and Etiquette Day was you got to dress up in your Sunday finest and the teachers served the kids. The custodians were the butlers. We had everybody working to show that there was a different way. We had the men tying the ties for the boys because they're not taught that. They don't have these positive male role models. So, one of the things that was important to me was to hire men. We had a lot of men. I had men that were disabled because I had big special ed population that was physically challenged. A big one. Like 20some buses a day.

So, I needed my babies to see I had teachers that were blind, I had teachers that were in wheelchairs or walkers. I needed my babies to see when I grow up even though I have this disability or that disability I can do that. So, I would have my blind teacher go up to the fifth and sixth grade and read to them in Braille, and they were like in awe. Why? Because she's doing it every day with her babies downstairs.

You need to respect that person because you're going to be a parent one day and one of your babies could be like that. And that was the conversation. So, I had to be real with them. If I caught you laughing at somebody or making fun, then you got to sit with me out in there. (Laughter)

JM: Fabulous story.

W: I was in there sitting with Miss Huggins.

JM: Fabulous, fabulous story.

SH: Everything that's been said, I'm not going to repeat it, but I do want to say something about this data, this emphasis on data.

JM: Right.

SH: It gives a false image of what is really happening in the school. First of all, some of the instruments are flawed that we're administering to the students. I remember I was with my data specialist and we were looking, this goes back a few years, looking at a third grade reading test. And they had multiple choice answers and he and I both came up with different answers. And eventually that question was taken out. So, I had inherited from my predecessor some really wonderful strategies to just keep abreast of what's happening in the school. Now my school was a small school, I had 320 children.

W: Wow.

W: Oh, wow.

W: Teeming, teeming, okay?

W: Three-hundred and twenty. 


\section{(Overlap/Inaudible)}

SH: I never had an assistant principal. I didn't have an assistant principal until my last two years somebody came in.

But what I did was, I continued the tradition of the monthly grade meetings and the collection of student work, top, middle, and bottom, and then we would have discussions in the group about what they saw. And it was very interesting in the beginning how simplistic my staff, many of them were, about what they were observing.

But as we continued the process they became more diligent, using the information in a different way. And I was always in classrooms so I would sit with children and talk with them and get a sense of what they knew or understood, or what they were questioning. The data specialists created spreadsheets and at first the teachers balked at this. "I do my own!" And I said, "But we need something that goes across the grade that is on the same method so that we can really ..." And once they saw it they settled down.

Again, I think that's another challenge, it was mentioned earlier, that when you have the union, and I do believe the union was a necessary entity in the system, but when it gets to a place where you forget why we are really here, and it's for children and educating them, and it's not about satisfying your needs as an adult then we can get somewhere. So, the teachers learned to disaggregate the data and talk more effectively about what they were seeing their students do. And they had to show the following month how they addressed and what the results were.

And they started coming in with suggestions for one another. And I could actually see the growth of their professionalism, their understanding of what they were doing. We used the unit tests of materials instead of just the city or the state exams. We also had workshops for parents because when I was a child we came into school, the teacher said, "Put away your things. Take out your two pencils," and this was your test. We didn't even know we were going to have the test.

W: That's true.

SH: Now it is test prep. I mean, the kids, I had kids who were just in tears going in for the test. Now I understand the kids' parents can opt out of the test. So anyway, so that data I didn't want to use, but I wanted the parents to understand. And we would talk about what we were doing and I would be the teacher at these workshops if I didn't cover another teacher to come in and do it.

And sometimes somebody had a better slant on something or had a strength in a particular area and I wanted to showcase that teacher, but I really wanted the parents to sit in the seats of their children to understand the pressures that they were putting on their children was unnecessary. But again, it's because of all of this furor about the school scores. I could care less about them. And I'm being very honest with it. I wanted to see light in the eyes of my students and I wanted them to be able to articulate what they were learning and to express what they were feeling, what they were curious about, and how they were going to go about it.

I had issues, and I still have issues, as I was an early childhood teacher, that what I was seeing that was happening in kindergarten in terms of the materials, first and foremost, the print was like this and that's not age appropriate. And I just saw children being set up just to be robots and I didn't want that as well. The reality is you do have the state tests, and it does impact on the score and the evaluation that you get in the end, but I was always juggling and trying to keep a balance so that we could be reasonable and not put undue pressure on our students.

Having said all of that, I have to confess I'm greatly relieved that I'm retired. (Laughter)

W: Hear, hear.

JM: I'll speak for myself, I'm sure Dr. Bryant can speak for herself. It has been a distinct pleasure to spend these few hours with some of the finest educators that I have come in contact with. And your willingness to share your thoughts and bring your perspectives to the educational scene today and what it takes to make it work, and to help people, and the students. It was a very, very fine discussion. And I'll tell you, Beverly and I were sitting down, we wanted to do something to show that there are other approaches to improving the education of students of color and disabilities.

And when I say students of color, also differences in culture. I had Prospect Heights High School, as you know, and I used to love to hear people say, "Oh, Prospect Heights is a homogenous school," and then I would joyfully say, "No, there are 21 different countries represented in that high school of 2,000 students." And this begins to help people to think globally. We can't do the same old thing in the same old way.

But I am sure when you are glad that you are retired, I don't believe it. And take it from somebody and, yes, as they say, "She's still around?" (Laughter) Yes, I am. Yes. And I've been taking notes and I've learned from 
you today. And thank you very, very much.

BB: And on my end, as you know, I know each one of you personally as well as professionally, and it was a pleasure getting you together and letting the people, the audience know that I was not alone as an African American educator.

That there are really a wealth of African American females who also not only succeeded, brought their gifts to the table.

One of you mentioned about the fact that most of you have been in that little underground social circle. All of you I've vented to in one way or the other. And the fact that we're able to succeed. And it's my pleasure to bring you guys over here to let everybody else know that there is a wealth out there and we're not alone. So thank you.

W: Thank you.

W: Thank you.

W: Thank you.

JM: Okay, thank you. And in the true Board of Education style, we'll send you thanks, but no money. (Laughter)

W: Touché, well said. Well said.

W: Very good.

W: Well said.

W: Thank you.

JM: That's the one thing that hasn't changed.

(Background Conversation)

(END OF TAPE) 